\title{
Nitrogen as a threat to European water quality
}

Book or Report Section

Published Version

Grizzetti, B., Bouraoui, F., Billen, G., van Grinsven, H., Cardoso, A. C., Thieu, V., Garnier, J., Curtis, C., Howarth, R. W. and Johnes, P. (2011) Nitrogen as a threat to European water quality. In: Sutton, M. A., Howard, C. M., Erisman, J. W., Billen, G., Bleeker, A., Grennfelt, P., van Grinsven, H. and Grizzetti, B. (eds.) European Nitrogen Assessment. Cambridge University Press, UK, pp. 379-404. ISBN 9781107006126 Available at https://centaur.reading.ac.uk/20869/

It is advisable to refer to the publisher's version if you intend to cite from the work. See Guidance on citing.

Publisher: Cambridge University Press

All outputs in CentAUR are protected by Intellectual Property Rights law, including copyright law. Copyright and IPR is retained by the creators or other copyright holders. Terms and conditions for use of this material are defined in the End User Agreement. 


\section{CentAUR}

Central Archive at the University of Reading

Reading's research outputs online 


\title{
Nitrogen as a threat to European water quality
}

\author{
Lead author: Bruna Grizzetti \\ Contributing authors: Fayçal Bouraoui, Gilles Billen, Hans van Grinsven, Ana Cristina Cardoso, \\ Vincent Thieu, Josette Garnier, Chris Curtis, Robert Howarth and Penny Johnes
}

\section{Executive summary}

\section{Nature of the problem}

- Anthropogenic increase of nitrogen in water poses direct threats to human and aquatic ecosystems. High nitrate concentrations in drinking water are dangerous for human health. In aquatic ecosystems the nitrogen enrichment produces eutrophication, which is responsible for toxic algal blooms, water anoxia, fish kills and habitat and biodiversity loss.

- The continuous nitrogen export to waters reduces the capacity of aquatic ecosystems to absorb, reorganise and adapt to external stress, increasing their vulnerability to future unexpected natural or climate events.

\section{Key findings/state of knowledge}

- Nitrogen concentrations in European rivers, lakes, aquifers and coastal waters are high in many regions. In addition nitrate concentrations are increasing in groundwaters, threatening the long term quality of the resource.

- In Europe, nitrogen pressures occur over large areas, implying elevated costs for meeting the long-term good chemical and ecological water quality requirements. A significant part of the European population could be potentially exposed to high nitrate values in drinking water if adequate treatments were not in place. Furthermore many of European aquatic ecosystems are eutrophic or at risk of eutrophication.

- Nitrogen pressures have reduced biodiversity and damaged the resilience of aquatic ecosystems and continue to pose a threat to the aquatic environment and to the provision of goods and services from the aquatic ecosystems.

- Even under favourable land use scenarios the nitrogen export to European waters and seas is likely to remain significant in the near future. The effects of climate change on nitrogen export to water are still uncertain.

\section{Major uncertainties/challenges}

- Policy tools are available within the European Union and under international conventions to mitigate the nitrogen pollution in water, but their full implementation has not been achieved yet throughout Europe.

- In many cases a delay in the water quality response to the implementation of measures have been observed, due to previous nitrogen accumulation in soils, sediments or aquifers or to inadequate design of the mitigation plans.

- The issue of pollution swapping between environmental compartments has appeared as an important element to be considered by both the scientific and policy prospective.

\section{Recommendations}

- To protect and enhance the European water resources the full implementation of the existing regulations related to nitrogen is necessary, in addition to an efficient environmental monitoring.

- Moreover, positive synergies could be obtained by encouraging the integration in the sectoral policies and enhancing interdisciplinarity in the scientific research, especially in support of regional assessments and pollution swapping evaluations.

The European Nitrogen Assessment, ed. Mark A. Sutton, Clare M. Howard, Jan Willem Erisman, Gilles Billen, Albert Bleeker, Peringe Grennfelt, Hans van Grinsven and Bruna Grizzetti. Published by Cambridge University Press. @ Cambridge University Press 2011, with sections $\odot$ authors/European Union. 


\subsection{Introduction}

Human activities are responsible for consistent $\mathrm{N}_{\mathrm{r}}$ export to the environment (Vitousek et al., 1997; Schlesinger, 2009; Erisman et al., 2011, Chapter 2 this volume). The enrichment of nitrogen in the aquatic system impairs the water quality of rivers, lakes, aquifers and coastal and marine waters, and contributes to the phenomenon of eutrophication (European Environment Agency, 2001; Durand et al., 2011, Chapter 7 this volume; Voß et al., 2011, Chapter 8 this volume; Billen et al., 2011, Chapter 13 this volume). $\mathrm{N}_{\mathrm{r}}$ is fundamental for global food production and is still insufficient in many world regions (Sanchez and Swaminathan, 2005). However, the significant anthropogenic nitrogen mobilisation through agricultural activities, waste water discharges and fossil fuels combustion produces detrimental impacts on the aquatic environment and affects both human and ecosystem health (Lavelle et al., 2005).

Estimates for year 2000 indicate that Europe is exporting 4.7 Tg of nitrogen per year to its seas (Bouraoui et al., 2009; Billen et al., 2011, Chapter 13 this volume) and trends show that the production of $\mathrm{N}_{\mathrm{r}}$ and its emission to the environment is accelerating because of the rise of agricultural demands and commercial energy production (Galloway et al., 2008). The aquatic ecosystems are able to remove a significant part of incoming nitrogen load but this capacity is not unlimited and strongly depends on the local ecosystem characteristics (Howarth et al., 1996; Kronvang et al., 1999a; Alexander et al., 2000; Mulholland et al., 2008; Durand et al., 2011, Chapter 7 this volume). Consequently there is a lot of uncertainty on the amount of self-purification of aquatic ecosystems (Seitzinger et al., 2006; Hejzlar et al., 2009) and on the capacity to absorb nitrogen pollution without undergoing radical changes (Millennium Ecosystem Assessment, 2005). In addition, nitrogen can build-up slowly in soil and water systems such as aquifers and reservoirs, and actual remediation practices might produce their effects only in the long-term (Jackson et al., 2008).

Europe is thus pouring nitrogen in its water resources affecting human and ecological systems at a rate that is unlikely to reverse in the near future and with consequences that are only partially understood. The socio-ecological systems have some capacity to absorb the pollution, reorganise and adapt to the external change, but this capacity is not unlimited and a slow change of the nitrogen pool may result soon or later in some chronic or drastic unexpected effects (Carpenter and Folke, 2006). In this context of uncertainty and variability, the challenge is to better understand the extent of nitrogen enrichment in water systems and the threats it poses for human and ecosystem health in the prospective of current changing drivers, such as climate change, land use change, pollution and economic growth, and to consider which mechanisms of adaptation and mitigation the science-policy interactions need to produce.

In this chapter we will try to address this challenge. The paper starts by illustrating the trend of nitrogen in European rivers, aquifer and coastal waters, in order to understand the intensity and the location of the problem. Next, the threats posed by nitrogen enriched waters to human health and aquatic ecosystem functioning are considered and then analysed further in the light of major future drivers, notably land-cover and climate changes. Finally, the paper proposes a reflection on the current adaptation and mitigation strategies and on the possibilities and positive synergies of science-policy interactions.

\subsection{Nitrogen enrichment in European waters}

\subsubsection{Nitrogen trends in European surface waters}

In Europe some efforts have been made during the last two decades to reduce the nutrient input from waste water discharge, but diffuse pollution from agriculture still remains a major threat for waters (European Environment Agency, 2005). Figure 17.1 shows the observed annual nitrates concentrations reported by OECD (2008) at the mouth of some major European rivers.

Trend analysis indicates that in Europe between 1992 and 2005 nitrogen and phosphorus concentrations remained relatively constant in lakes while they decreased in rivers (European Environment Agency, 2009). In fact, there was a slight decrease of nitrogen concentrations in European rivers compared to the values of the 1990s, except in southern Europe, and phosphorus concentrations have significantly declined, reflecting the general improvement in wastewater treatment and the reduction of phosphates in detergents (European Environment Agency, 2005). Yet, in Europe, trends in nutrient concentrations vary according to the different regions depending on local conditions. According to the information provided by the Member States on surface water quality (European Commission, 2007 $\operatorname{COM}(2007) 120)$, between the two periods 1996-1999 and 2000-2003, the nitrate concentrations decreased in 55\% of the monitoring stations and were stable in $31 \%$. However, in $14 \%$ of the monitoring locations nitrate concentrations were increasing. Stations reporting increasing trends were located in Luxembourg, France, United Kingdom, Portugal and Belgium, while decreasing and stable trends were found in Denmark, Austria, Ireland, Sweden, Germany and the Netherlands (European Commission, 2007 COM(2007)120). These trends need to be evaluated regionally and considering the contemporary changes in nitrogen sources. In fact, between the two above mentioned periods, nitrogen input of mineral fertiliser and manure declined by $6 \%$ and $5 \%$, respectively (European Commission, $2007 \operatorname{COM}(2007) 120)$, atmospheric deposition slightly decreased (Simpson et al., 2011, Chapter 14 this volume) and nutrients point discharges were reduced by improving waste water treatments (European Environment Agency, 2005). Therefore, in certain areas nitrate concentration in surface waters may have remained constant in spite of some reduction in nitrogen inputs. According to data provided by Member States (EU27) in the last Nitrates Directive reporting exercise covering 2004-2007, nitrate concentration is increasing in $30 \%$ of the monitoring stations, while it is stable or decreasing in $70 \%$ of the stations (European Commission $2010 \operatorname{COM}(2010) 47)$.

The current concentrations in rivers generate significant nitrogen loads to the seas (Billen et al., 2011, Chapter 13 


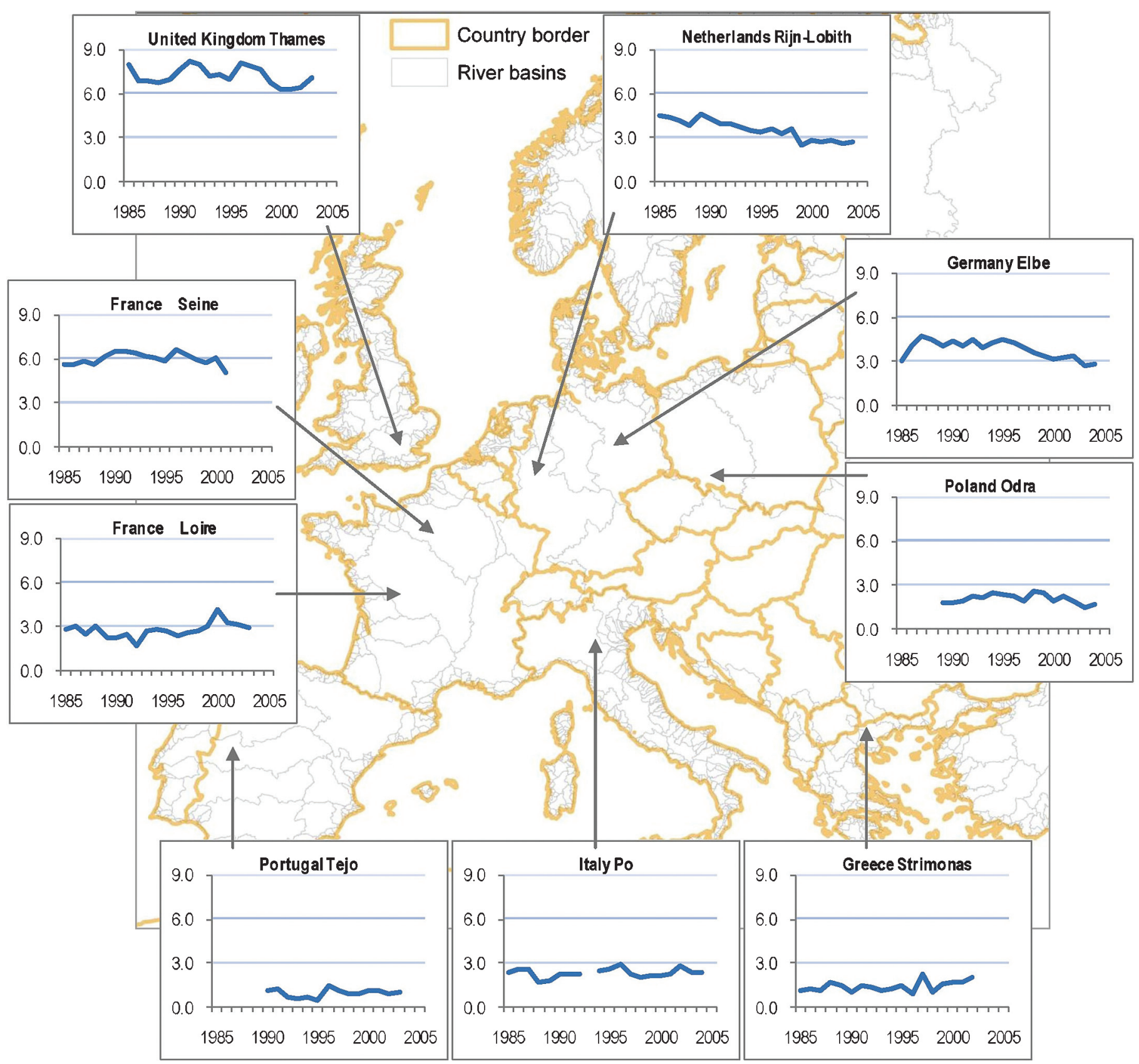

Figure 17.1 Annual nitrate concentrations (in mgN/l) in surface water at the mouth of some major European rivers (from OECD, 2008).

this volume). In European coastal waters, nitrate concentrations have remained generally stable in the Baltic, North and Celtic Seas and have increased in some Italian coastal areas (Figure 17.2; European Environment Agency, 2005). Artioli et al. (2008) compared nitrogen budgets for European seas over three periods: before eutrophication, during severe eutrophication and in current situation. According to their study in the Baltic Proper nitrogen and phosphorus riverine loads remained stable since the eutrophication period (1955-1985), in the Coastal North Sea nutrient inputs have declined after the severe eutrophication period (ending around 1990), and in the Northern Adriatic Sea riverine loads have increased for nitrogen, while they have been halved for phosphorus as a result of phosphate banning policies in detergents. For more details on nitrogen trends in the European Seas see Voss et al., 2011 (Chapter 8 this volume).

\subsubsection{Nitrogen accumulation in aquifers}

Groundwater is an important resource in Europe, providing water for domestic use for about two third of the population but groundwater is a finite and slowly renewed resource and overexploitation associated with a degradation of water quality is putting in danger an important source of drinking water. In Europe, groundwater nitrate concentrations have remained stable and high in some regions (European Environment Agency, 2005). In the Third Assessment Report on the Implementation of the Nitrates Directive, the European Commission (European 


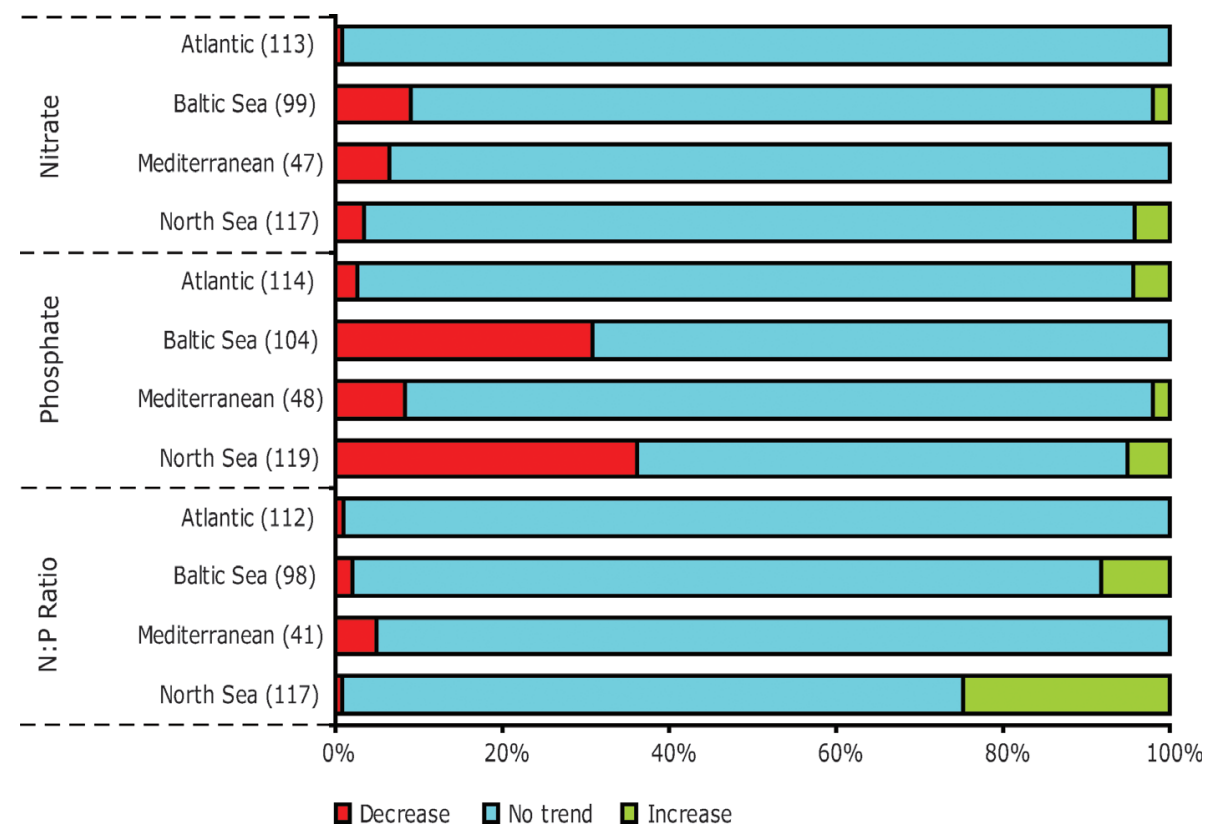

Commission, $2007 \mathrm{COM}(2007) 120)$ reports that for the period $2000-2003$ about $17 \%$ of the wells in EU15 exhibit a concentration of nitrate above the limit of $50 \mathrm{mg} / \mathrm{l}$. An additional 7\% were in the range between 40 and $50 \mathrm{mg} / \mathrm{l}$, while about $60 \%$ were below $25 \mathrm{mg} / \mathrm{l}$. Analysing the trend between the third and second assessment report, the European Commission found that even though $30 \%$ of the reported wells show an improvement in their concentration of nitrate, an alarming 36\% show an increasing trend (European Commission, 2007 $\operatorname{COM}(2007) 120)$. According to the last assessment report, covering the period 2004-2007, nitrate pollution in groundwater is still observed in $34 \%$ of the monitoring stations, with $15 \%$ of the stations with nitrate concentrations above $50 \mathrm{mg} / \mathrm{l}$ (European Commission, 2010 COM(2010)47).

Background concentrations of nitrate in groundwater are very low. Most of the nitrates found in groundwater are thus of anthropogenic origin and mostly related to agricultural activities. Van Drecht et al. (2003) estimated the total leaching of nitrogen to groundwater at $55 \mathrm{Tg} / \mathrm{yr}$ at the global scale with a contribution of $8 \mathrm{Tg} / \mathrm{yr}$ for Europe, of which $40 \%$ will reach the rivers outlets. Contribution of deep aquifers mostly affected by historical use of fertiliser was estimated at $10 \%$ of the total load of nitrogen. These calculations were made at the global scale and might hide some spatial and temporal variations, however they agree with some more detailed estimates. Behrendt et al. (2003) estimated the groundwater contribution to total load of nitrogen to be $48 \%$ for the Danube for the period 1998-2000. Schreiber et al. (2003) analysing all German catchments found a groundwater contribution ranging from $38 \%$ to $69 \%$. Palmeri et al. (2005) estimated the contribution of groundwater to total nitrogen load in the Po Valley to be around 36\%. Even though highly variable and dependent on the degree of agriculture intensification and hydrogeological properties of the aquifers, groundwater is a significant source of nitrogen at the catchments outlets.
The quantity of nitrate present in the groundwater is strongly linked to the amount of nitrogen applied in agricultural land, and to the nitrogen surplus in particular. Indeed nitrogen surplus in agricultural land can be removed by surface runoff, leaching to the aquifer, and loss to the atmosphere or can be stored in the soil-water system. Bouraoui et al. (2009) estimated the surplus of nitrogen for Europe at $11.5 \mathrm{Tg}$ for year 2000 and $10 \mathrm{Tg}$ for 2005 (Figure 17.3). This surplus was calculated without considering volatilisation from manure as this pathway is an additional pressure on the environment (details on surplus computation are given in the legend of Figure 17.3). At European scale, there is a decrease of nitrogen surplus for many countries (see Figure 17.3). Dramatic decreases are observed in the Netherlands, Denmark, and Germany where the nitrogen surplus is back to the level of that of 1970 . However, there is still no strong evidence that the groundwater level is responding to the decrease of nitrogen surplus. The most striking cases are those of the Eastern countries that have seen a decrease by half of the nitrogen surplus, due to the economic and political changes at the beginning of the 1990s. Improvement in the water quality observed in streams is yet to respond to these changes, as large quantities of nitrate are stored in the aquifers and are released slowly depending on groundwater residence time, which may vary from weeks to several thousands of years (Alley et al., 2002; Schlesinger, 2009). In addition, nitrogen stored in the soil system might be released slowly due to the mineralisation process (Stalnacke et al., 2004; Grimvall et al., 2000), and nitrate residence time in the unsaturated zone. For example, Sileika et al. (2006), analysing long term data on nitrate concentrations in Nemunas River (Lithuania), noted a strong increase of nitrates in surface water from the Soviet period despite the large drop in fertilisation, due among other to a large storage and accumulation of soil nitrogen during the Soviet period.

Even though no clear conclusion can be drawn on the response time of aquifers to changes in fertiliser application, 


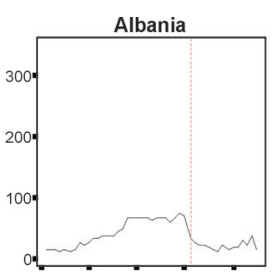

Bulgaria

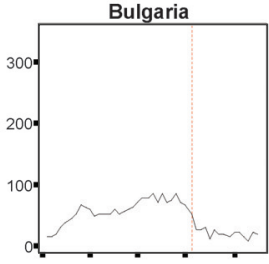

Estonia

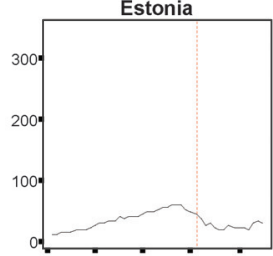

Germany

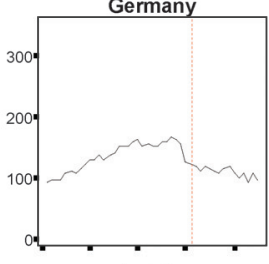

Latvia

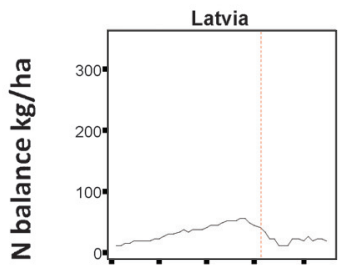

Netherlands
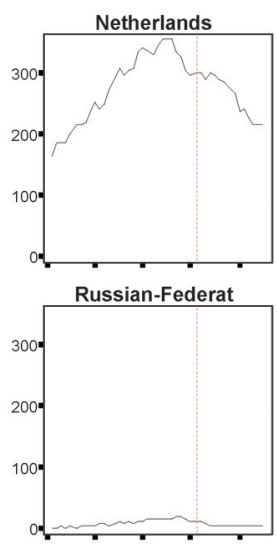

Sweden

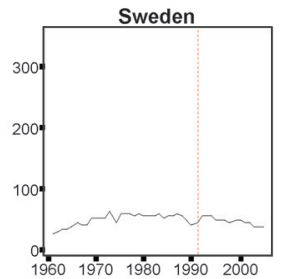

Austria

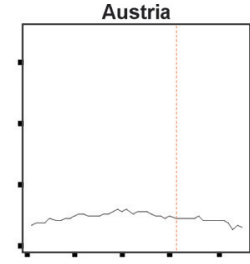

Croatia

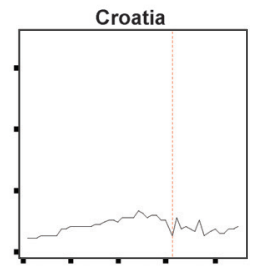

Finland

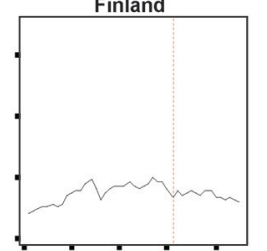

Greece

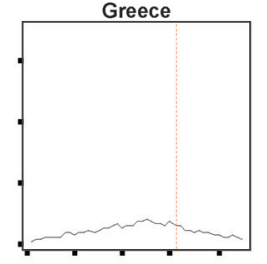

Lebanon

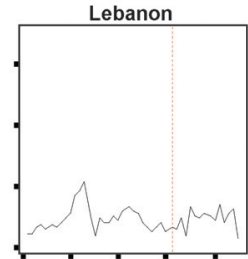

Norway

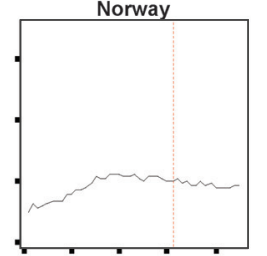

Serbia-Monteneg

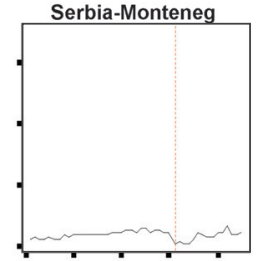

Switzerland

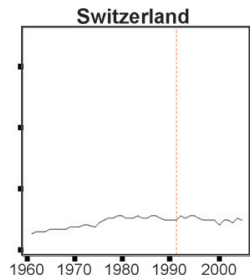

Belarus

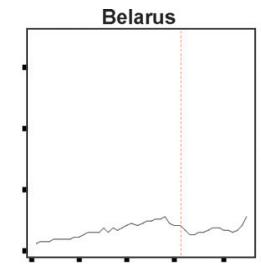

Cyprus

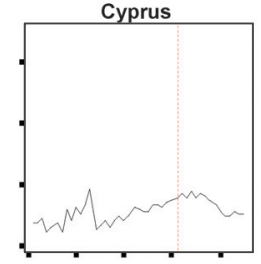

France

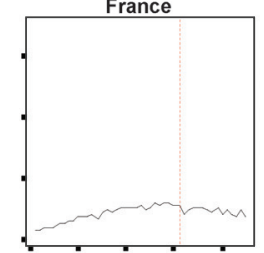

Hungary

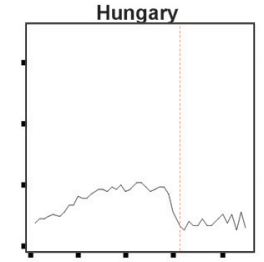

Lithuania

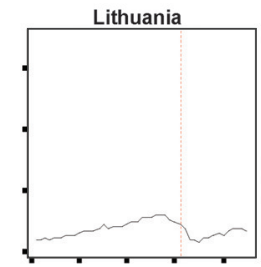

Poland

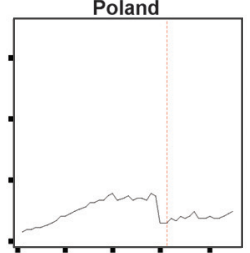

Slovakia

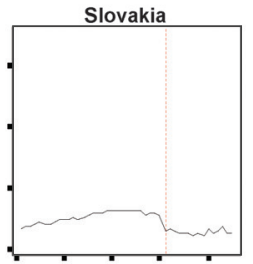

Turkey

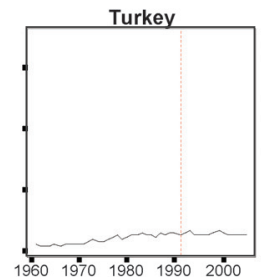

Year
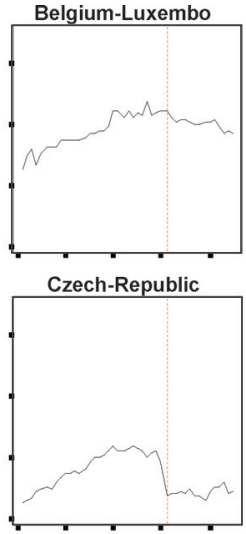

FYR-Macedonia

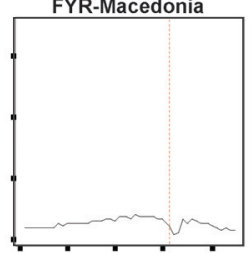

Ireland

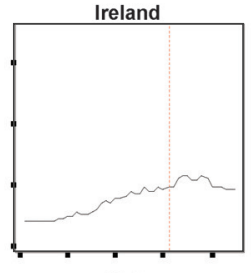

Malta

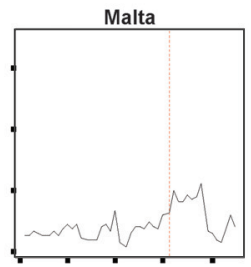

Portugal

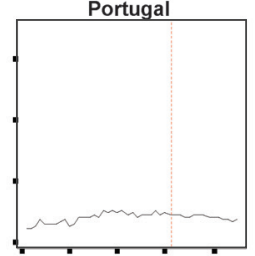

Slovenia

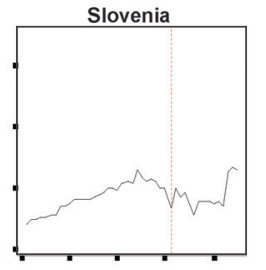

Ukraine

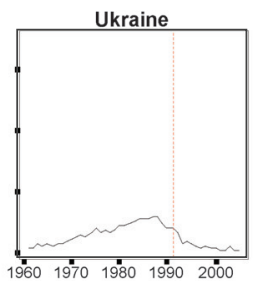

Bosni-Herzegovi

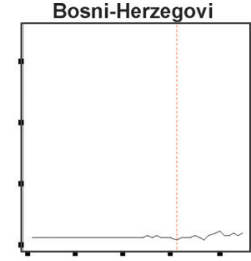

Denmark

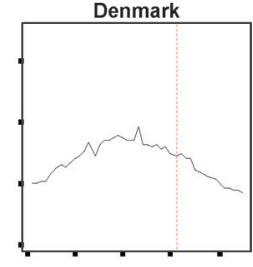

Georgia

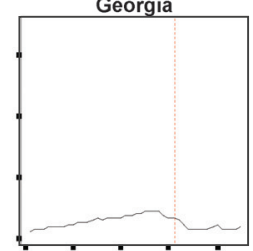

Italy

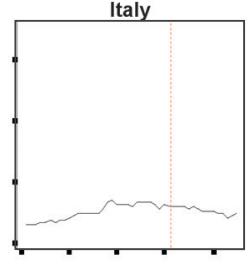

Moldova

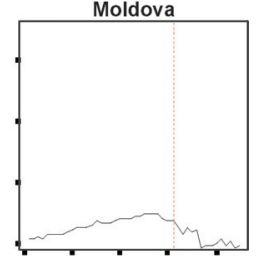

Romania

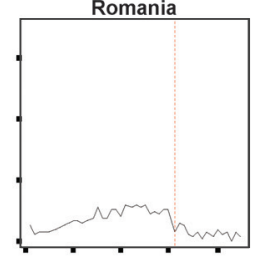

Spain

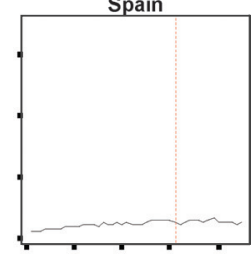

United-Kingdom

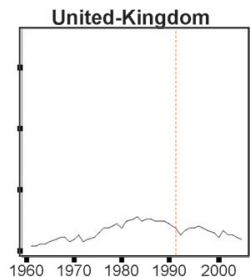

Figure 17.3 Estimated nitrogen surplus for European and some

Mediterranean countries

( $k g \mathrm{~N}$ per ha of agricultural

land). The red bar indicates the year of implementation of the Nitrates Directive (1991/676/EEC). Nitrogen surplus is computed

using a simple national mass balance approach.

The inputs considered

include: mineral application of nitrogen (source FAO),

nitrogen from manure application calculated using animal number (source FAO) and excretion coefficients non-corrected for

volatilisation, atmospheric nitrogen deposition (source EMEP), symbiotic biological fixation (calculated as the nitrogen in crop harvest for soybean and pulses), non-symbiotic fixation (estimated at $25 \mathrm{~kg} / \mathrm{ha}$ for rice and $5 \mathrm{~kg} / \mathrm{ha}$ for other upland crops). The output considered was crop harvest taken as the crop yield (source: FAO) multiplied by nitrogen crop content coefficients. 
it can be expected that past unbalanced fertiliser strategies will impact for a long time the quality of European groundwater and in turn the surface water quality. Wriedt and Bouraoui (2009) estimated the average residence time for continental Europe for elementary river basin of about $100 \mathrm{~km}^{2}$ based on river density, slope, and parent material properties. According to these estimates, northern countries are characterised by shorter residence time (less than five years) and one can expect a faster reaction of the groundwater to any improved fertilisation strategy. Longer residence time are calculated in Southern Europe, Southern England (Chalk area), Poland, and along the North Sea Coast of Europe and thus any management decision to reduce nitrate load to groundwater might take decades to see any positive effect.

All this evidence indicate that in Europe the past and current anthropogenic activities are impacting and might impact water resources for the years and decades to come. Indeed, nitrogen surplus from agriculture is still high in many countries and huge quantities of nitrogen are stored in the soil or aquifers. There are some major concerns as the Eastern countries will probably intensify their agriculture and thus their fertilisation rate in the near future, and some countries of Western Europe have not seen their nitrogen surplus decrease but rather stabilise at high levels. Efforts have been taken, through conventions or the application of binding Directives, and still Europe's waters are suffering from excess nitrogen. It is a complex task to estimate how and how long it will take to restore Europe's waters to good quality. So it is still a priority to assess how this excess nitrogen is affecting both human and ecosystems health, and evaluate how this impact will vary in a changing environment.

\subsection{Threats for human and ecological aquatic systems}

\subsubsection{The human-ecological system}

The human and the environmental systems are strictly interconnected. Humans are altering the natural nitrogen cycle to increase their benefits from nature, but they are affected by the changes they are causing in the environment. This section analyses the threats induced by the nitrogen enrichment in European waters considering humans and aquatic ecosystems as the principal receptors of impacts in a context of inherent mutual relation for which human actions affect ecosystems and the impaired ecosystems affects human health and well-being.

The Millennium Ecosystem Assessment has highlighted the benefits that people obtain from nature, the ecosystem services, and the tight link between human and ecological systems (Millennium Ecosystem Assessment, 2005). Ecosystem services include provisional services, such as food, fresh water, wood and fibre; regulating services, which affect water purification and regulation of climate, flood and disease; cultural services, which provide recreational, aesthetic and spiritual benefits; and supporting services, such as nutrient cycling, soil formation and primary production (Millennium Ecosystem
Assessment, 2005). These services support livelihood and development of human society and their sustainable use is fundamental for the human wealth and security (Folke et al., 2002). Water and nitrogen are directly or indirectly involved in all the ecosystem services. Nitrogen in aquifers and reservoirs impairs water quality for drinking purpose, affecting directly the human health. Nitrogen enrichment in lakes, rivers and coastal and marine waters may produce the phenomenon of eutrophication which has detrimental effects for aquatic ecosystems. Consequently, the ecosystem per se is damaged and some services such as fish provision or aesthetic and recreational uses are directly affected. Moreover, through the intensive mobilisation, the nitrogen cycle and primary production may become distorted and some regulating services may be reduced or compromised. For example evidence shows that busting denitrification through additional nitrogen input in the water system may increase the emission of $\mathrm{N}_{2} \mathrm{O}$ to the atmosphere, which acts as a strong greenhouse gas affecting the climate. Studies have highlighted that the efficiency of water purification may be reduced increasing the total amount of nitrogen input in the river system (Mulholland et al., 2008), and that aquatic ecosystems significantly impacted by eutrophication are more vulnerable to flood events and diseases spreads (Folke et al., 2004; McKenzie and Townsend, 2007). Thus, altering the nitrogen availability in water is likely to significantly affect the social and environmental system, reducing many ecosystem benefits.

The socio-ecological system has some capacity, resilience, to 'absorb disturbance and reorganise while undergoing change so as to still retain essentially the same function, structure, identity and feedbacks' (Walker et al., 2004). Resilience is often associated with diversity, such as biological species and economic options, to support the ecosystem capacity to renew and reorganise into a desired state although under pressure (Carpenter and Folke, 2006). Moreover, the actors of the socio-ecological system have the possibility to adapt to ongoing changes in order to moderate the undesired effects and as well to try to reverse them. However, this ecosystem ability to absorb stress and recuperate is not linear and is possible only until a certain threshold (tipping point), beyond which the recovery is difficult or impossible, leading to a regime shift. Human degradation of the environment has reduced the ecosystems resilience, shrinking the ability to mitigate natural hazards (Carpenter and Folke, 2006) and increasing the likelihood of drastic changes to less desired capacity to generate ecosystem services (Scheffer et al., 2001; Folke et al., 2004).

There are various ways in which nitrogen enrichment of water can affect human and aquatic ecosystem health. Direct effects from use of drinking water have been described extensively in the scientific literature and are the subject of current policies. Indirect effects such as from eutrophication are less well known. In the following part we describe the threats on human health due to nitrogen in drinking water and then the threats on aquatic ecosystems and their consequent indirect effects on human health and well being, providing, where possible, estimates at European scale. 


\subsubsection{Effects of nitrogen rich drinking water on human health}

Currently in many countries there are strict limits on the permissible concentration of nitrate in drinking water and in many surface waters. The limit is $50 \mathrm{mgNO}_{3} / \mathrm{l}$ in the European Drinking Water Directive (Directive 98/83/EC) and $44 \mathrm{mgNO}_{3} / 1$ in the United States (equivalent to $11.3 \mathrm{mgN} / \mathrm{l}$ and $10 \mathrm{mgN} / \mathrm{l}$, respectively). These limits are in agreement with $\mathrm{WHO}$ recommendations established in 1970 and recently reviewed and reconfirmed (WHO, 2007; the exact formulation of the standard is that the sum of $\mathrm{NO}_{3} / 50+\mathrm{NO}_{2} / 3$ should not exceed 1). The European Nitrates Directive also sets a limit concentration of $50 \mathrm{mgNO}_{3} / \mathrm{l}$ for groundwater and surface water, as a threshold value for Member States to protect water bodies.

There are two main health issues related to nitrate in drinking water: the linkage with infant methaemoglobinaemia, also known as blue baby syndrome, and with cancers, for example of the digestive tract (Ward et al., 2005). The evidence for nitrate as a cause of these serious diseases is controversial (Powlson et al., 2008; Salomez and Hofman, 2003). In addition there is evidence for increased cardiovascular health with increased nitrate intake (Webb et al., 2008). Presently, it is widely accepted that methaemoglobinaemia in Europe is rare, and that in general incidence is related to presence of pathogens in drinking water rather than to nitrate or nitrite (Addiscott, 2005).

The emerging and returning question is whether nitrate in drinking water is harmful to humans, and if the drinking water standard in some cases could be increased (van Grinsven et al., 2006; L'hirondel and L'hirondel, 2002). Such an increase would have great implications for policies, measures and costs related to water treatment and to fertiliser and manure application. To answer this question, the following points are relevant.

- Only a small proportion $(<20 \%)$ of nitrate intake in most humans is related to drinking water, most nitrate intake comes from meat and vegetables.

- Nitrate is a major component in human metabolism and harmless for humans. However, N-nitroso compounds, derived from nitrate (through nitrite), are probably carcinogenic to humans. Ingested nitrate or nitrite under conditions that result in endogenous nitrosation is probably carcinogenic to humans. The underlying mechanism is endogenous nitrosation, which in the case of nitrate must be preceded by reduction to nitrite. Nitrosating agents that arise from nitrite under acidic gastric conditions react readily with nitrosatable compounds, especially secondary amines and alkyl amides, to generate $\mathrm{N}$-nitroso compounds, many of which are carcinogenic (IARC, 2006).

- The WHO-standard of $50 \mathrm{mgNO}_{3} / \mathrm{l}$ is a compromise that does not account for the possible role of nitrate as a precursor for carcinogenic N-nitroso compounds.

- It is virtually impossible to relate incidence of cancers to nitrate in drinking water, in view of the presence of many nitrate sources, the complexity of nitrogen metabolism and many life style and diet factors enhancing or preventing cancers. Epidemiological studies suggesting an association between nitrate in drinking water and various health defects are therefore rare (Ward et al., 2005).

Reasons for policy to consider health risk associated with increased nitrate in drinking water are the chronic and potentially massive exposure, the empirical evidence for increased risk and the fairly easy options to prevent exposure.

An additional emerging issue is related to the formation of carcinogen N-Nitrosodimethylamine (NDMA) upon disinfection of drinking water. Disinfectants may react with other compounds (precursors) in the water, like pesticides and their degradation products, to form NDMA. The latter is a potent carcinogen that is not easily removed by normal drinking treatment procedures (Schmidt and Brauch, 2008). Depending on environmental conditions and presence of nitrosamine precursors, disinfectant treatment may even enhance NDMA formation (Zhao et al., 2008). NDMA may become a future threat, but the role of dissolved inorganic and organic nitrogen in NDMA formation is not yet clarified.

\section{Tentative European assessment}

\section{Drinking water sources}

In Western Europe almost $100 \%$ of the population has access to safe drinking water, while in the Eastern part the proportions vary from $58 \%$ to $80 \%$, with lower values for rural areas, where only $30 \%-40 \%$ of households have access to safe drinking water (WHO, 2007). In European countries with lower GDP or large rural areas, substantial proportions of the population have no connection to public water supply. Safety and adequacy of drinking water supply in areas with no public supply or small local facilities are expected to be less systematically monitored and therefore not guaranteed.

In Europe, water for drinking use is abstracted from aquifers, rivers or reservoirs, according to the regional availability of the resource, and then treated for human consumption. According to the information reported by the European Commission (2007) for the period 2002-2004, the relative shares of surface water, groundwater and other sources to the production of drinking water were $66 \%, 33 \%$ and $4 \%$, respectively. These values represent an average of the information reported by $14 \mathrm{EU}$ Member States and refer only to larger water supply zones, which served about $78 \%$ of the total population living in the EU14 countries. Figure 17.4 reports the relative use of water resource for drinking purposes per country (European Commission, 2007). Groundwater is the main source for drinking water in Austria, Denmark, Italy, Spain, Germany, France, Belgium and the Netherlands, while the use of surface water is dominant in Finland, Czech Republic, Estonia, Ireland, Portugal and United Kingdom.

Large parts of the European population consume bottled mineral water and beverages (UNESDA, 2009), which, in general, are low in nitrate and nitrite (Griesenbeck et al., 2009). In EU27, the average annual consumption of bottled drinking water increased from around $87 \mathrm{l} /$ capita in 2001 to $106 \mathrm{l} /$ capita in 2007. Consumption varies in the different countries, 


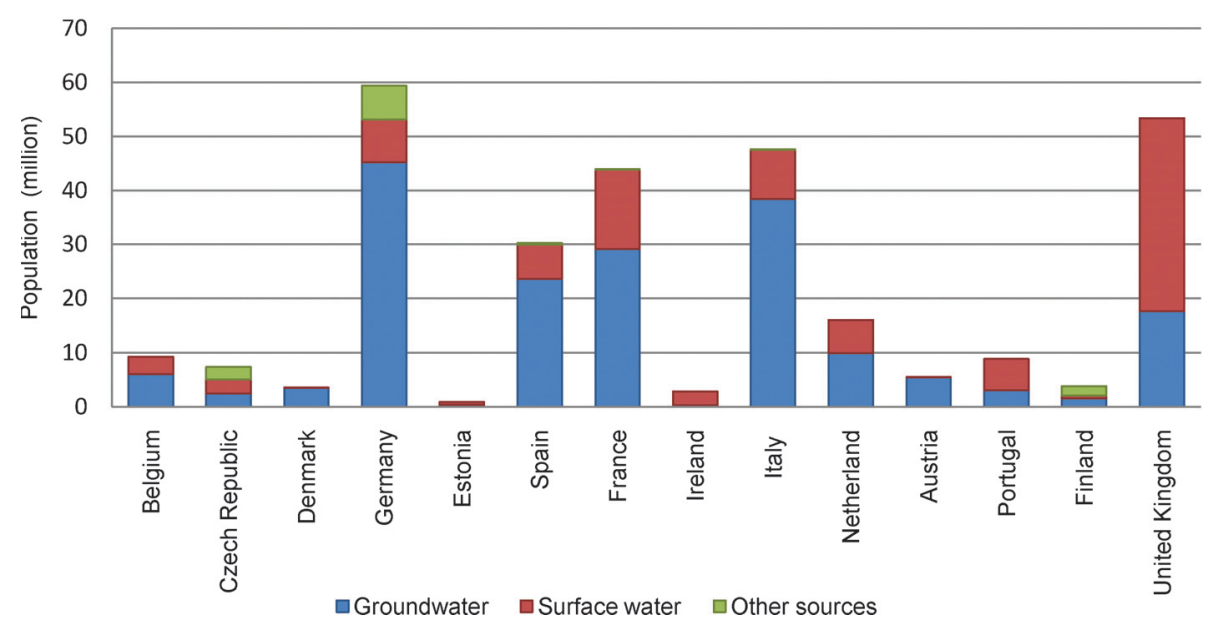

Figure 17.4 Relative contributions of surface water, groundwater and other sources to the production of drinking water in 14 EU Member States. The production of drinking water is expressed as population served per country by larger water supply zones (source: European Commission, 2007). mainly as a consequence of specific cultural and market driven lifestyles.

\section{Drinking water quality}

The EU Drinking Water Directive (Directive 98/83/EC) requires Member States to report drinking water quality to the Commission every three years. In the synthesis report for 2002-2004 (European Commission, 2007) nitrate is listed as one of the parameters most often causing non-compliance in the larger water supply zones (serving more than 5000 persons or producing over 1 million litres per day). The synthesis report points out that it is not easy to draw conclusions on trends in water quality for individual Member States and for Europe in view of the often very incomplete or incompatible country reports. Percentage of non-compliance is no direct indicator of potential exposure to drinking water exceeding the nitrate or nitrite limit, in fact non-compliance may be incidental and restricted to specific water supply zones and the mandatory reporting does not cover small supply zones. For example in Denmark about 30\% of the population is served by smaller facilities, in Austria, France, Germany and Ireland the proportion is close to 25\% (European Commission, 2007). Non-compliance for nitrate or nitrite is reported regularly but rarely exceeds $4 \%$ and is restricted to a similar proportion of monitored and reported supply zones.

\section{Assessment of potential exposure}

Considering data from 12 of the EU15 Member States, van Grinsven et al. (2006) estimated that almost 3\% of the population using drinking water from groundwater resources is potentially exposed to concentrations exceeding $50 \mathrm{mgNO}_{3} / \mathrm{l}$, and $5 \%$ to concentrations exceeding $25 \mathrm{mgNO}_{3} / \mathrm{l}$ (see also van Grinsven et al., 2010). De Roos et al. (2003) and Gulis et al. (2002) found evidence of $25 \mathrm{mgNO}_{3} / \mathrm{l}$ as a critical concentration for health effects. Exceedance is caused both by untreated private supply and insufficiently treated public supply.

Combining the information on population density and estimates of nitrate concentration in European surface waters (Figure 17.5), it results that around half of the European population lives in areas with nitrate concentrations higher than $25 \mathrm{mgNO}_{3} / \mathrm{l}$, and about one fifth in areas with values higher that $50 \mathrm{mgNO}_{3} /$, with variations by country (Figure 17.6).
In the USA, Dodds et al. (2009) have analysed the potential economic damages caused by eutrophication in American freshwaters with regard to drinking water use, considering the spending for bottled water. The estimated associated cost for bottled drinking water consumption in the EU27 is significant (Figure 17.7). However, people consume bottled drinking water not only because of concern about drinking quality but also because of social-cultural preferences.

In addition to drinking water treatments, other costs are encountered by the society related to the health problems caused by nitrogen enrichment in drinking water. However, they are difficult to estimate because of the scarcity of targeted epidemiological studies. Van Grinsven et al. (2010) provide an assessment of social cost of colon cancer due to nitrate in European drinking water. They estimate a 3\% increase of incidence for 11 Western European countries, corresponding to a health loss of 2.9 euro/capita per year. For a more detailed discussion on costs related to nitrogen pollution see Brink et al., 2011 (Chapter 22, this volume).

\subsubsection{Effects of nitrogen on the aquatic ecosystems health}

The anthropogenic increase of nitrogen and phosphorus in lakes, reservoirs, rivers and coastal waters is the main cause of eutrophication. The phenomenon was observed in temperate lakes during the 1960s (OECD, 1982) but it rapidly expanded to estuaries and coastal seas. In general, in aquatic ecosystems the increase of nutrient concentration promotes the phytoplankton growth and generates an imbalance between algal production and consumption. As a result, biomass sedimentation and microbial decomposition are enhanced and a large part of bottom-water oxygen is consumed (Durand et al., 2011, Chapter 7, this volume; Voss et al., 2011, Chapter 8, this volume).

As nitrogen is a crucial element for photosynthesis and primary production, its significant enrichment in the water medium directly alters fundamental processes of the aquatic ecosystem. The role of nitrogen in water eutrophication depends on its relative availability with respect to other elements, such as carbon, phosphorus and silica (Billen and Garnier, 2007). Scientists use the concept of the 'limiting 

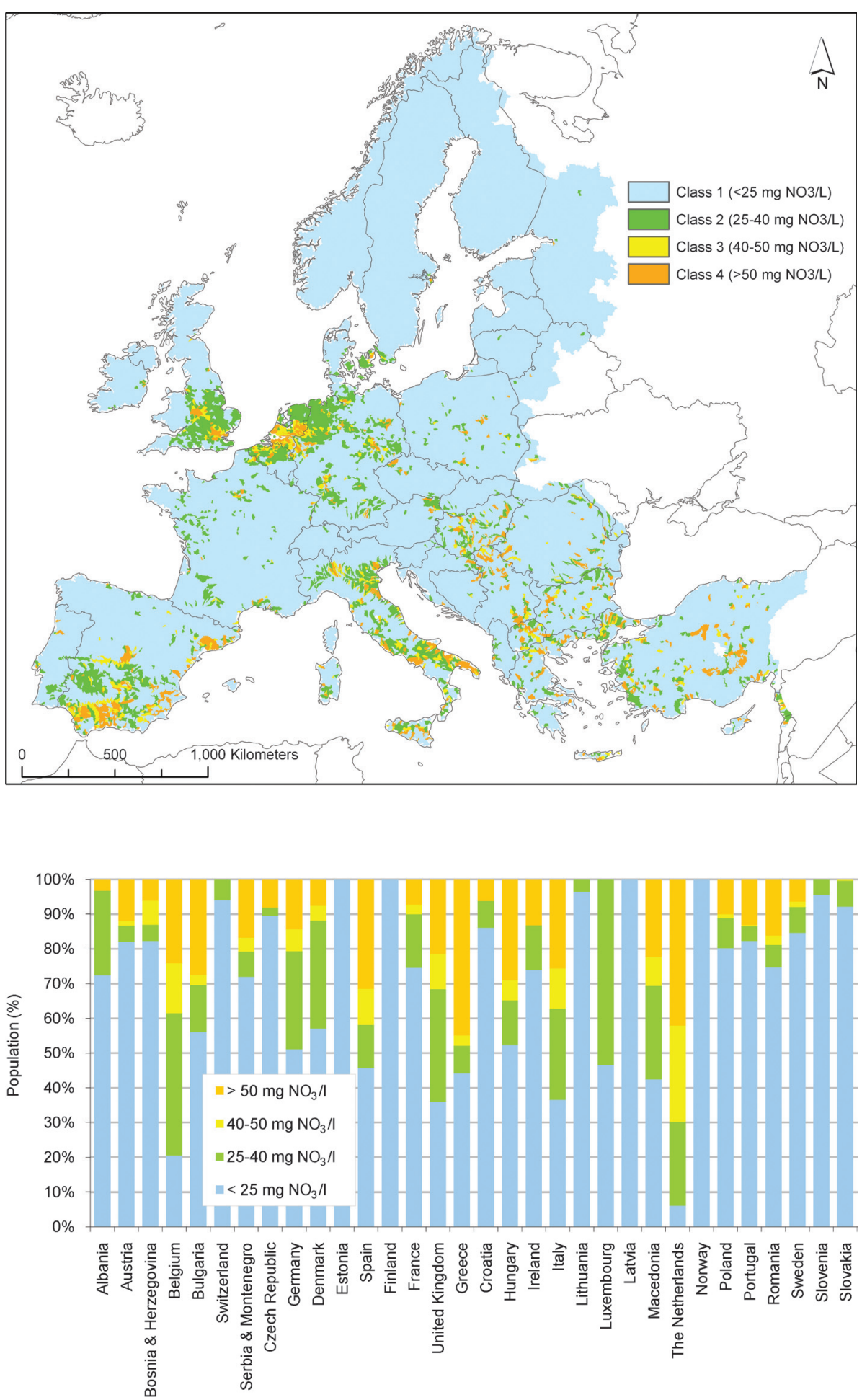

Figure 17.5 Estimated nitrate concentration in surface waters for year 2000. The spatial units of analysis are sub-catchments of $180 \mathrm{~km}^{2}$ average size (data are derived from the estimates of Bouraoui et al., 2009).
Figure 17.6 Percentage of population living in areas with different average nitrate concentration in surface waters. The values derive from the overlay between population density per subcatchment and estimated nitrate concentration in the relative surface water (shown in Figure 17.5). element', which is the element that limits the potential rate of primary production (Howarth, 1988). It has often been observed that freshwaters are limited by phosphorus, whereas marine waters by nitrogen. However, this is a general simplification and each aquatic system has its peculiarities. In fact, in freshwaters, estuaries and coastal marine ecosystems the limiting role between nitrogen and phosphorus may change seasonally and spatially (Conley et al., 2009). For a thorough discussion on limiting element, nutrient ratios and their effect on the quality of freshwaters and coastal and marine waters see Durand et al. (2011), Voss et al. (2011) and Billen et al. (2011, Chapters 7, 8 and 13 this volume).

Eutrophication causes many negative effects on the aquatic ecosystem (for extensive review see Carpenter et al., 1998; Cloern, 2001; Smith, 2003; Smith and Schindler, 2009). Table 17.1 summarises some of the main effects. 


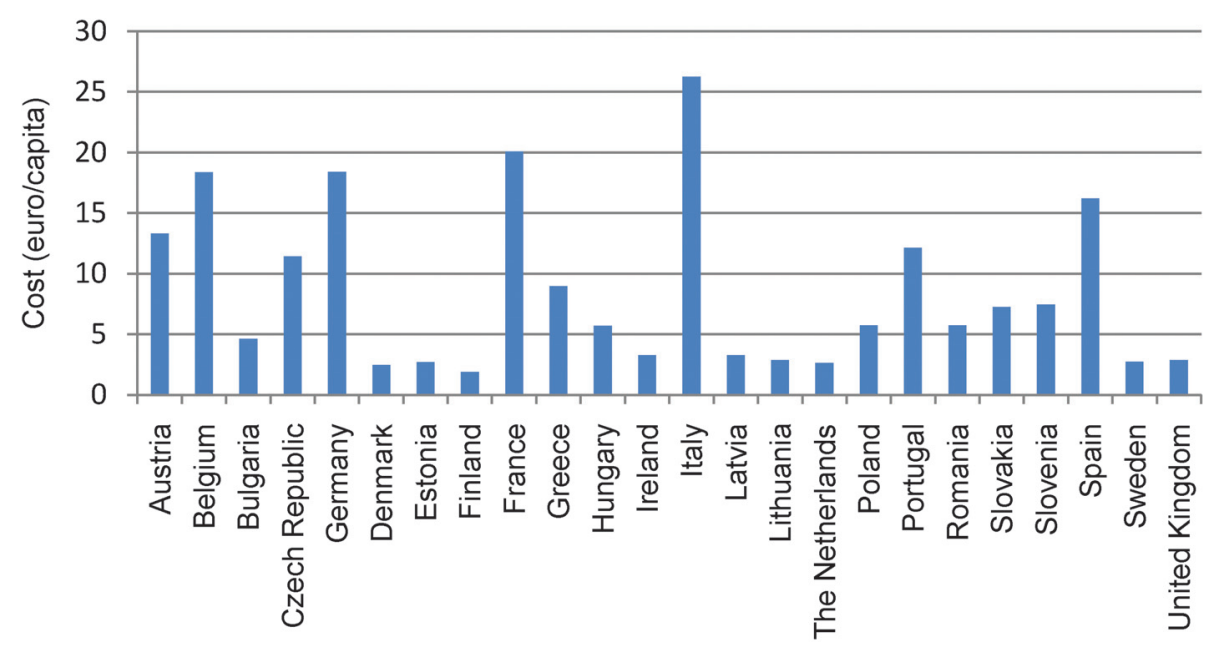

Figure 17.7 Estimated cost for bottled drinking water per capita per country. Estimates refer to year 2001. Data on packaged water consumption per capita are taken from UNESDA (2009). An average cost of 0.15 euro/l is assumed for the estimation.

Table 17.1 Adverse effects caused by eutrophication in aquatic ecosystems (from Smith and Schindler, 2009, and references therein)

\section{Effects of eutrophication}

Increased biomass of phytoplankton and macrophyte vegetation

Increased biomass of consumer species

Shifts to bloom-forming algal species that might be toxic or inedible

Increases in blooms of gelatinous zooplankton (marine environments)

Increased biomass of benthic and epiphytic algae

Changes in species composition and macrophyte vegetation

Decline in coral reef health and loss of coral reef communities

Increased incidence of fish kills

Reduction in species diversity

Reduction in harvestable fish and shellfish biomass

Decreases in water transparency

Taste, odour and drinking water treatment problems

Oxygen depletion

Decreases in perceived aesthetic value of the water body

Excessive nutrient loading produces an increase of algal biomass and a change in the species composition of the algal communities (Smith, 2003). Eutrophication can induce a progressive selection in phytoplankton towards fast-growing species. Bloom-forming algae (Figure 17.8) may be directly toxic for the components of the aquatic ecosystem and for humans and impairs waters for fisheries, recreation and drinking (Carpenter et al., 1998). The consequent sedimentation and decomposition of the dead algae depletes oxygen in bottom waters, especially in ecosystems with low rate of water turnover. Anoxic conditions kill benthos and fishes and cause extensive loss of habitats. Increasing coastal zones with significant oxygen depletion (dead zones) were reported in the last half of

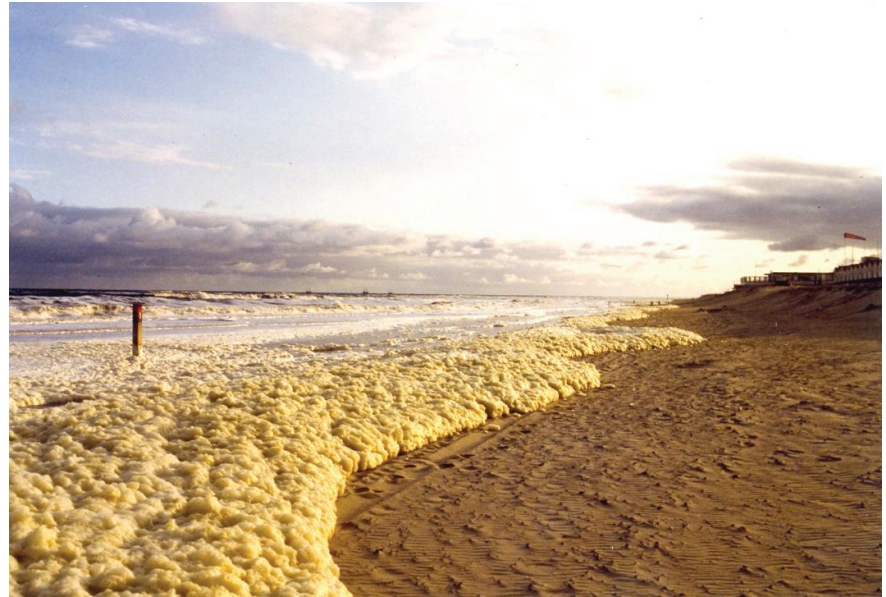

Figure 17.8 Picture of Phaeocystis foam in Texel, the Netherlands. (Source: Gilles Billen.)

the twentieth century in the Adriatic Sea, the Black Sea, the Kattegat and the Baltic Sea (Diaz and Rosenberg, 2008).

Some algae can produce toxins that can be adsorbed or ingested via drinking waters or feeding by aquatic animals and humans. Cyanobacteria, dinoflagellates and diatoms are among the main taxonomic groups contributing to toxic algae blooms and evidence shows that their occurrence can be stimulated by nitrogen pollution (Camargo and Alonso, 2006). There are clear indications that nutrient enrichment enhances harmful algal blooms (HABs), and some evidence of a connection between increased urea fertiliser use and HABs (Glibert et al., 2006). In all cases, the linkages between HABs and eutrophication are complex and include nutrient enrichment as well as indirect pathways (Anderson et al., 2002).

The explosive growth of undesired algae, with the consequent oxygen depletion, may induce important changes in the habitat quality and affects both the species abundance and community composition, introducing some alterations in the trophic web. For example, in shallow coastal areas the changes from perennial macroalgaes and seagrasses to ephemeral macroalgaes, produced by nutrient enrichment, may cause loss of 
habitat for aquatic animals (Burkholder et al., 2007). Similarly, proper habitat for macroalgae or benthos may shrink where water transparency or oxygen availability decline.

Evidence has shown that eutrophication reduces the richness and abundance of aquatic species. 'Nutrient enrichment can cause a change in the selective forces that regulate the biological diversity at all trophic levels within the coastal food webs' (Cloern, 2001). Moreover, eutrophication and human actions promote the invasion of exogenous species, which further contribute to reducing the native biodiversity. According to Lotze et al. (2006), who performed a study considering 12 temperate estuarine and coastal ecosystems covering Europe, North America and Australia from prehistory to actual times, by the end of the twentieth century, $7 \%$ of the recorded species were extinct and $91 \%$ were depleted. Moreover, land reclamation, eutrophication, diseases and destruction were responsible for the destruction of $67 \%$ of wetlands, $65 \%$ of seagrasses, and $48 \%$ of submerged aquatic vegetation. However, major impacts on diversity, structure and functioning of the coastal ecosystems were due to overexploitation and habitat destruction, and eutrophication was only part of the problem (Lotze et al., 2006).

Diversity enhances the ecosystem stability and supports ecosystem services: fisheries, provision of nursery habitats and filtering and detoxification services (Worm et al., 2006). Large collapses of marine fisheries occur in species-poor ecosystems (Worm et al., 2006). Collapse of fish stock is related as well to unsustainable fishing and loss of habitat.

Nitrogen pollution can also more directly affect fish populations and fishery yields, with both positive and negative consequences (National Research Council, 2000). Up to a point, increased loads of nitrogen to coastal marine ecosystems can increase secondary production - including fish production - as primary production increases and more energy cascades up the food web (Nixon, 1988). However, with further inputs of nitrogen to the ecosystem, hypoxia, anoxia, and other changes in the ecosystem can lead to lower production of fish and less fish harvest. Caddy (1993) hypothesised that the effects would be seen on demersal fish, due to greater adverse consequences of eutrophication on the benthos, with adverse consequences on pelagic fish occurring only at greater nutrient loads. Because of the high variability in fish populations and fish harvests, collecting data to demonstrate the responses suggested by Caddy (1993) has been difficult. However, recently, Oczkowski and Nixon (2008) showed that for the fisheries of the Nile delta, the relationship between nitrogen load and fish does indeed follow a threshold response: fish catch increase with nitrogen load to a point, but beyond the threshold, fish catches fall significantly.

Recent research studies have raised the question about the influence of nitrogen enrichment in aquatic ecosystem and the dynamics of parasitic and infectious diseases. Pathogen infections directly threaten humans, animals and aquatic ecosystem health. Although direct experiments are rare in literature, the available evidences confirm a significant positive correlation between increased nutrients and diseases (McKenzie and Townsend, 2007; Hartikainen et al., 2009). Eutrophication can contribute to infectious diseases spread directly, enhancing the replication rate of aquatic pathogens, or indirectly, influencing the abundance and distribution of pathogens hosts and vectors. Through experimental mesocosmos studies, Johnson et al. (2007) have shown that eutrophication enhances amphibian disease, increasing the density of infected snail hosts and the per-snail production of parasites. Camargo and Alonso (2006) have reported several studies describing algal blooms associated with cholera outbreaks and showing positive correlation between inorganic nutrient concentrations and larval abundances of mosquitoes, which are potential carriers of pathogenic micro-organisms. More studies are needed to understand the possible links between nitrogen enrichment and infection disease risk, especially in the presence of other environmental stressors (Smith and Schindler, 2009). This could be relevant for European aquatic ecosystems, which are likely to face in the near future temperature increases, with a consequent change in geographic distribution of insects and mosquitoes.

The effects of eutrophication on the availability and the biochemical cycle of non-nutrient pollutants, such as heavy metals, pesticides, pharmaceutical and hormones have not been thoroughly explored yet, especially for emerging pollutants. Altering the physico-chemical properties of the water medium, like hindering light penetration and oxygen availability, eutrophication may influence the biodegradation of some compounds or create more favourable conditions for pollutants release from sediments. Supplies of nitrogen and phosphorus support bacterial growth and as a consequence can enhance the biodegradation of chemicals, such as aromatic hydrocarbons and pesticides (Smith and Schindler, 2009). Accelerating the phytoplankton and benthic growth, eutrophication increases the exchanges with water and bioaccumulation through the trophic chain, but it could produce as well a growth dilution effect. Therefore, the actual synergies between eutrophication and non-nutrient contaminants strictly depend on the characteristics of the chemicals, the physico-chemical conditions of the system and the local specific food web functioning.

In addition to the effects caused by eutrophication, the role of nitrogen deposition in contributing to surface water acidification is well recognised (Durand et al., 2011, Chapter 7 this volume). Sulphur has been the main agent contributing to acidification but due to large reductions in sulphur dioxide emissions over Europe since 1980, nitrogen has become more important. Although sulphur deposition is still a main agent of acidification around Europe, some regions (such as parts of the UK, Italy and the Alps) experience such high levels of nitrogen deposition that even if sulphur deposition could be eliminated completely, nitrogen deposition alone would still cause critical load exceedance and long-term acidification (Curtis et al., 2005a, b).

\section{Tentative European assessment}

Eutrophication is the result of nutrient enrichment in the aquatic system, but the severity of the phenomenon largely depends on the specific regional characteristics, climate, morphology, water residence time, nutrient concentration and ratio, trophic web status, and generally on the ecosystem resilience. Therefore, 
similar nutrient loads may produce different effects because of the regional sensitivities, and in particular of the relative availability of the other nutrients. Nevertheless, nitrogen and phosphorus concentrations, being the major driving forces of the problems, can be used as a proxy to evaluate the risk of water eutrophication (Phillips et al., 2008). According to Camargo and Alonso (2006) who performed an extensive study on the ecological and toxicological effects of inorganic nitrogen pollution in aquatic ecosystems, total nitrogen levels lower than 0.5-1.0 mg/l might prevent aquatic ecosystems from developing eutrophication and acidification. This does not apply for ecosystems naturally rich in nitrogen.

The total nitrogen concentration was used as a proxy to evaluate the potential risk of surface water eutrophication

Table 17.2 Classes of potential risk of eutrophication for surface water related to total nitrogen concentrations

$\begin{array}{ll}\begin{array}{l}\text { Level of potential risk of } \\ \text { euthropication }\end{array} & \begin{array}{l}\text { Total nitrogen } \\ \text { concentration }(\mathbf{m g} / \mathbf{l})\end{array} \\ \text { Low } & <0.5 \\ \text { Medium } & 0.5-1.5 \\ \text { High } & >1.5\end{array}$

Values are based on literature (Guidance Document on Eutrophication from Intercalibration Group; Vollenweider et al., 1976; OECD, 1982; Cardoso et al., 2001) at European scale. Three classes of potential risk were established based on the literature (Vollenweider et al., 1976; OECD, 1982; Cardoso et al., 2001) and on the information available from the Water Framework Directive Intercalibration Exercise (Guidance Document on Eutrophication from Intercalibration Group). The classification of total nitrogen concentration in classes of potential risk is shown in Table 17.2. These values, which are in agreement with the ecological thresholds reported in other studies (Durand et al., 2011, Chapter 7 this volume), were combined with estimates of total nitrogen concentrations in European surface waters (Bouraoui et al., 2009) to derive a European map of potential risk of eutrophication related to nitrogen (Figure 17.9). The map (Figure 17.9) shows that large parts of European water courses may be threatened by potential risk of eutrophication due to nitrogen concentrations. The risk varies with countries but is generally lower in the Scandinavian region (Figure 17.10). Figure 17.11 reports the potential risk of eutrophication per country for European inland wetlands using the same nitrogen concentration classification.

The Water Framework Directive requires that Member States evaluate the ecological status of their surface waters based on the deviation in the status of a number of biological elements (such as phytoplankton and macrophytes) from the water body type specific reference condition. The division of water bodies into types and the establishment of type specific reference conditions should allow for better resolving the effects on the biological elements (biological

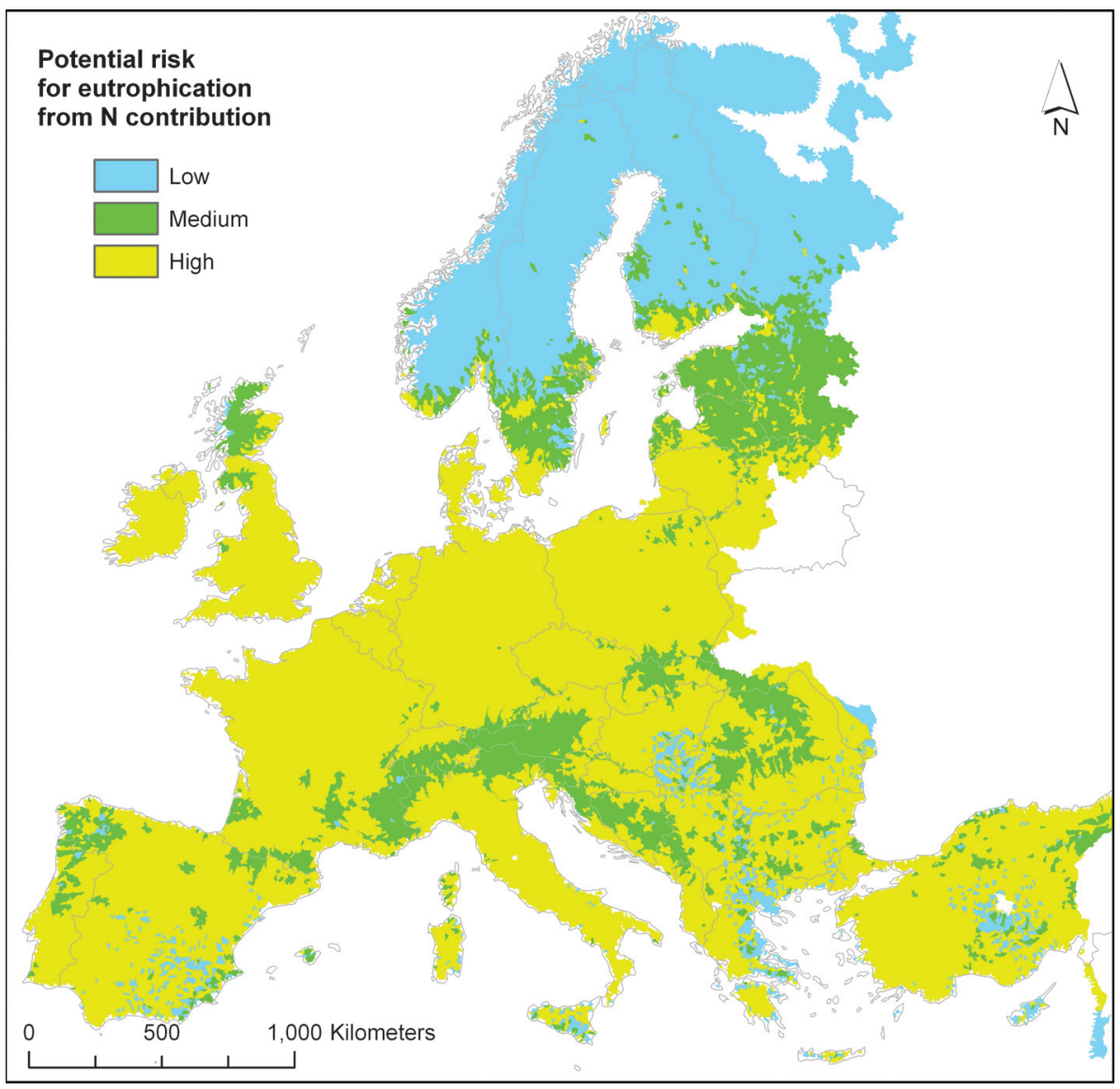

Figure 17.9 Map of potential risk of eutrophication for surface freshwater based on estimated total nitrogen concentrations. The map shows three classes of nitrogen concentration estimated in surface waters associated with a potential risk of eutrophication. The related total nitrogen concentration per class of risk is reported in Table 17.2. 

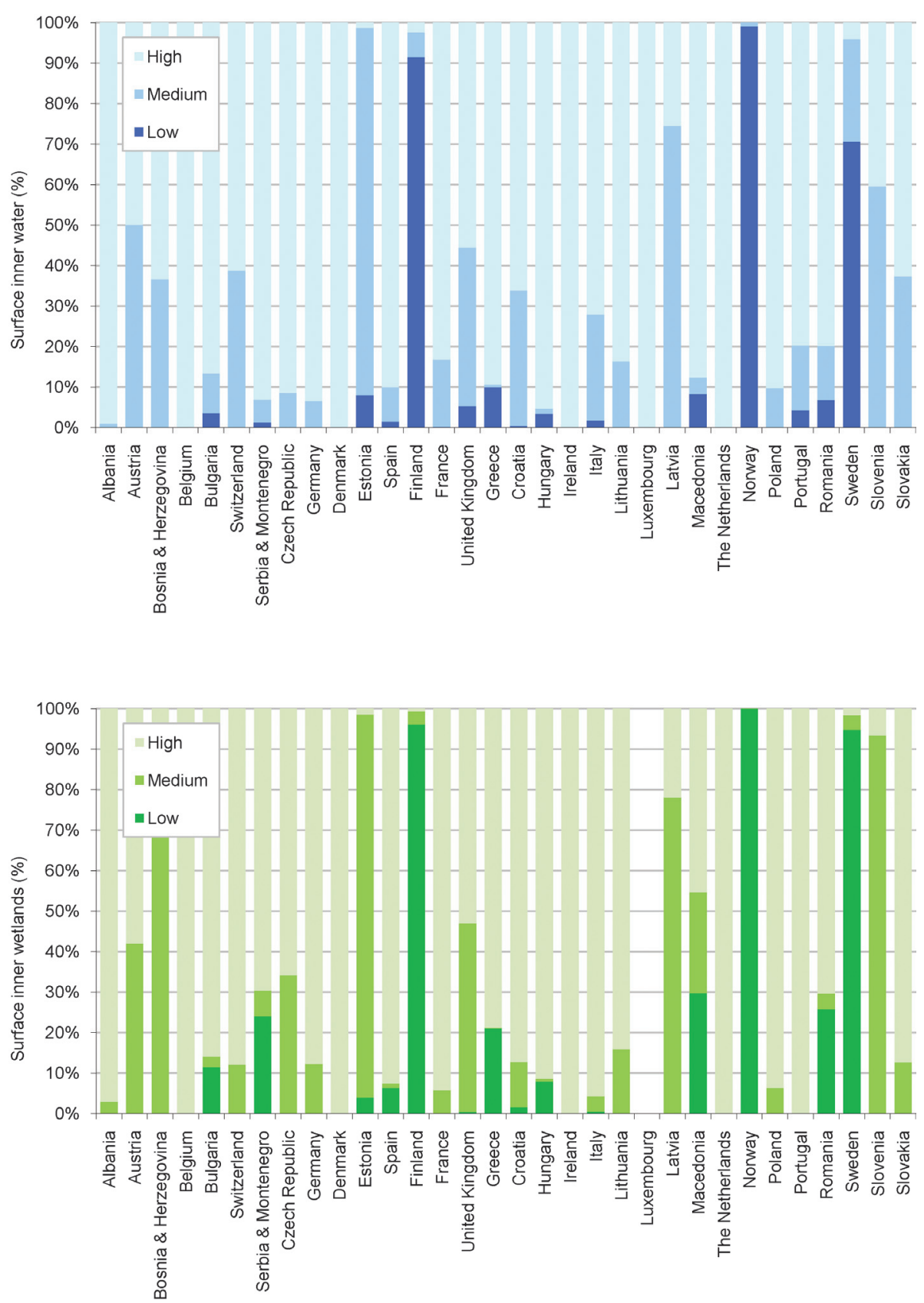

Figure 17.10 Percentage of surface of inner waters per class of potential risk of eutrophication related to total nitrogen concentration (see Table 17.2) per country. Inner waters refer to Corine Land Cover 2000 classes 40 and 41 (water courses and water bodies, respectively).
Figure 17.11 Percentage of surface of inner wetlands per class of potential risk of eutrophication related to total nitrogen concentration (see Table 17.2) per country. Inner wetlands refer to Corine Land Cover 2000 classes 35 and 36 (inland marshes and peat bogs, respectively). communities) from the variation associated to natural pressures (such as natural water fluctuations) and thus a more precise evaluation of the ecological condition. Figure 17.12 shows the ecological status of the European lakes, based on data that have been collated as part of the Water Framework Directive Intercalibration exercise (2004-2007). The ecological status of lakes was evaluated by chlorophyll-a values by the Mediterranean, Atlantic, Central/Baltic and Northern Geographic Intercalibration Groups (GIG), while for the Northern GIG the ecological status evaluation included chlorophyll-a values and indicators of the status of macrophytes communities' composition.

Concerning water acidification, within Europe, nitrogen and sulphurs emission ceilings are set to prevent critical load exceedance under both the Gothenburg Protocol of the UN-ECE Convention on Long-range Transboundary Air Pollution (CLRTAP) and the EU National Emissions Ceiling Directive (NECD) (see Hettelingh et al., 2007, 2008). Five countries currently submit freshwater critical loads data to the international mapping and modelling programme under the CLRTAP; the UK, Norway, Sweden, Finland and Switzerland (Canton Ticino). However, impacted acid sensitive lakes and streams are present in many other countries including France, Spain, Italy, Austria, Poland, Slovakia, Czech Republic, Romania, Bulgaria and Germany (Curtis et al., 2005b; Evans et al., 2001). The critical load of total nitrogen deposition, when excluding the effects of sulphur deposition, is $<400 \mathrm{eq} / \mathrm{ha}$ per year across large areas of Scandinavia and parts of the UK and the 


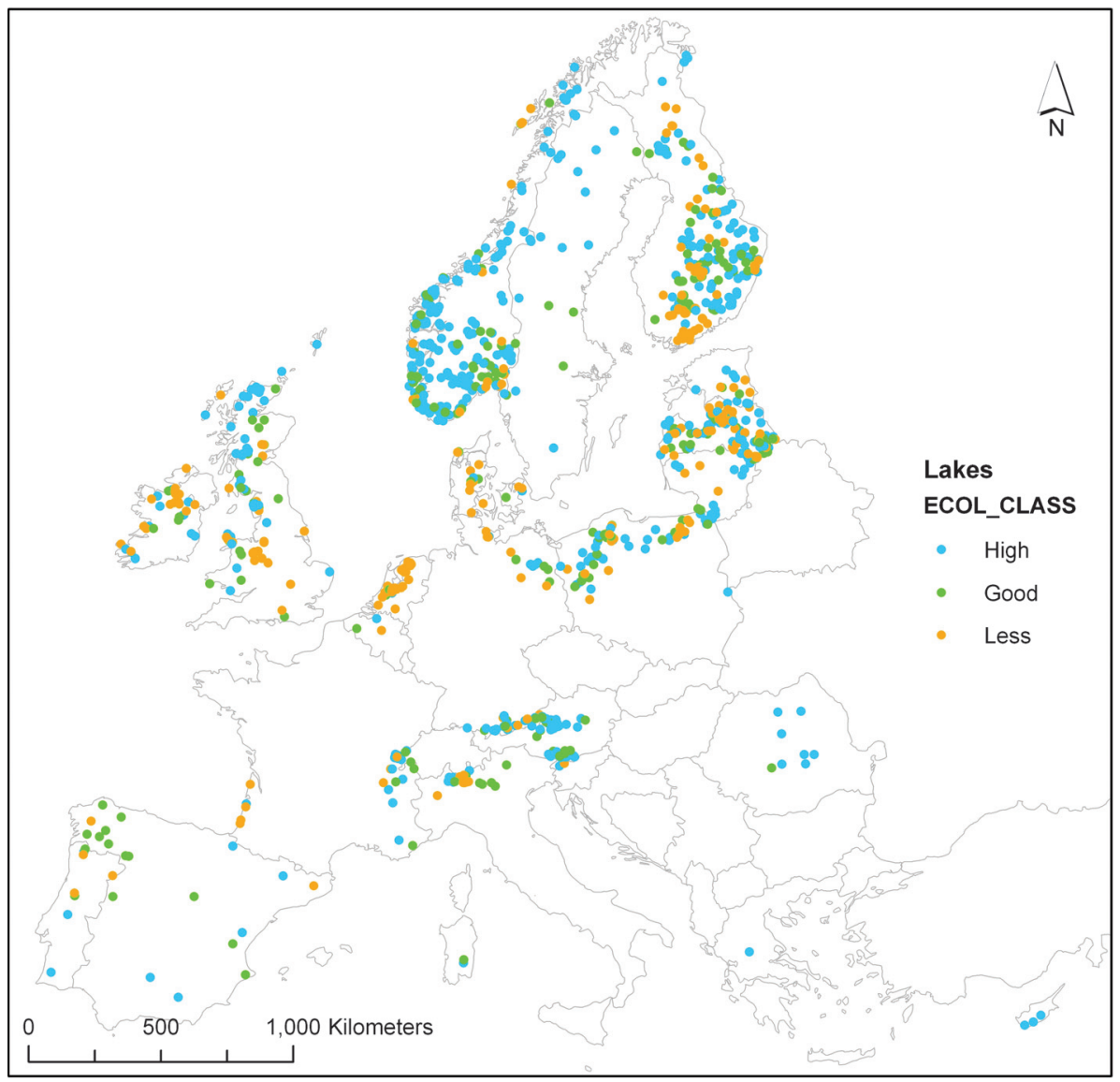

Figure 17.12 Ecological status of European lakes according to the harmonised methodology of the Water Framework Directive Intercalibration Group (in most of the region the ecological status is evaluated by chlorophyll-a values, explanation in the text). The lakes are subdivided in three main classes of High, Good and Less Good ecological status (Lake Intercalibration data provided by the Lake Geographical Intercalibration Groups and available at CIRCA folders: http://circa.europa.eu/ Members/irc/jrc/jrc_eewai/library. Data organised by Sandra Poikane, Joint Research Centre).
Swiss Alps and these deposition levels are exceeded across large regions of Europe (EMEP, 2009).

\subsection{Prospects for European water quality}

\subsubsection{Impact of climate change on freshwater quality}

Most striking expected climate change is a continental global warming from $1{ }^{\circ} \mathrm{C}$ to $4{ }^{\circ} \mathrm{C}$ more pronounced during winter in Eastern Europe and in summer for Southern and Western Europe. Precipitation exhibits a strong north to south gradient with an increase in northern Europe and a decrease going south (Alcamo et al., 2007) and a more pronounced seasonality. In addition there is a high probability of increase of extreme events. These changes will affect directly and indirectly the quality of freshwater and coastal and marine waters in Europe (Battarbee et al., 2008; European Environment Agency, 2008). Indeed the predicted climate change will affect the nutrient cycling in the water bodies, but will also affect the generation and transport processes of nitrogen originating from land based sources. The impact of climate change on water quantity has been studied extensively while fewer researches have focused on the impact of water quality. Water quality and nutrient concentrations in particular, will be affected by water quantity due to dilution or concentration effects, mobility, residence time and water temperature impact (Ducharne et al., 2007; Whitehead et al., 2009). Direct impacts of increased temperatures will be accelerated nutrient cycling (Whitehead et al., 2009; Murdoch et al., 2000). Furthermore, climate change or global change in general often results in synergistic effects of the different stressors (temperature increase, precipitation and land use change). It is thus very difficult to isolate the single effect of each stressor on the fate of nitrogen.

In southern European countries it is expected that climate change will result in lower runoff, exacerbated by increased water abstraction for irrigation purposes and growing human consumption. An increase in the number of intermittent streams and drought periods is also expected. The higher population release of nutrients due to eating habits with an associated increased industrial production will release increased amount of nutrients in the lower water volume resulting in both higher nutrient loads but also higher nutrient concentrations in the water courses due to point source discharges, unless additional treatment is applied (Eisenreich, 2005). Higher nutrient concentrations downstream of point discharges (industries, concentrated animal management operations) are also predicted by Whitehead et al. (2009) and Murdoch et al. (2000). Concerning agriculture, even though in Southern countries the decrease in water precipitation is expected to result in lower nutrient loads, the concentration of nutrients might increase due to lower water volume circulating in the streams (Mimikou et al., 2000). Therefore, for southern regions, an increased contribution of point sources relative to diffuse sources is anticipated with associated management problems. 
In northern regions, higher precipitation may also increase nutrient loads, and higher temperatures are likely to enhance nitrogen mineralisation. Ducharne et al. (2007), studying the Seine river basin, predicted that an increase of temperature by $2.3{ }^{\circ} \mathrm{C}$ will result in an increased soil nitrogen mineralisation from $8 \%$ to $26 \%$. Taking into account all processes enhancing or decreasing nitrogen production from mineralisation, they expected a net increase of $20 \%$ for nitrate leaching and nitrate in streams if appropriate farming practices are not implemented. Bouraoui et al. (2002), evaluating the impact of six climate change scenarios for the River Ouse (UK), found that climate change will increase nutrient losses to surface water due to the combined effects of increased mineralisation and the increased amount of water circulating through the soil profile. Wilby et al. (2006), who studied the impact of climate change on water resources in the River Kennet (UK), also predicted increasing concentrations of nitrates and ammonium until 2050. They estimated that due to the increased occurrence of summer drought, nitrates will build up in the soils and will be flushed into the streams when droughts break. Bouraoui et al. (2004) evaluated the impact of observed climate change occurring in Finland and predicted that the increase in temperature associated with the increased winter runoff due to accelerated snowmelt results in higher nitrogen loading by about $3 \%$ with pronounced seasonality. They found increased losses of nitrogen during the winter and reduced loads during the traditional snow melt period. Similar conclusions were reached by Arheimer et al. (2005) when studying the Ronnea catchment (Sweden). The authors predicted an increased nitrogen loading due to increased winter precipitation and increased mineralisation from soil organic matter despite an increase in surface and groundwater nitrogen retention. The increased retention under the climate change scenarios is attributed to increased temperature, increased nitrogen concentration and drier summer conditions yielding a longer transit time in the summer, the most active season for nitrogen removal process. They also noticed an extension of the areas contributing to the total nitrogen loads, with obvious management implications.

Assessing the impacts of climate change on nutrient loads or concentration in freshwater and coastal ecosystems is not straightforward as many other factors impact their status and health. Eutrophication is not only controlled by nutrient availability but is also affected by light conditions, temperature, residence time, flow regime. Invasion of non-native species will obviously depend on temperature, flow conditions but also on nutrient availability and cycling (Murdoch et al., 2000; Rahel and Olden, 2008). The impact of climate change on freshwater ecosystems has been studied in controlled experiments in mesocosms tanks (Feuchtmayr et al., 2007; Christoffersen et al., 2006; Moss et al., 2003). Feuchtmayr et al. (2007) showed in their experiment that higher nutrient concentrations would result in increased population of four out of eleven of the macroinvertebrates used in their study. McKee et al. (2003) measured an increase in zooplankton abundance under increased nutrient addition. Moss et al. (2003) showed that nutrient addition (unlike warming) increased phytoplankton chlorophyll a concentration and total algal biovolume, and did not affect the number of species. In northern boreal regions where lentic and lotic ecosystems are oligotrophic, an increase of nutrient loads might lead in earlier stages to an increase of biodiversity. Conversely, in southern boreal countries where freshwater ecosystems are eutrophic, an increase in nutrient loads could result in a decrease of biodiversity. Under the combination of increased temperature and nutrient inputs, arctic lakes will exhibit an increase algal production and biomass leading to a potential colonisation of predatory fish (Flanagan et al., 2003).

The impact of climate change on ecosystems has been studied through the detailed analysis of dry years and even droughts. Many authors report that under increased temperature, blooms of the harmful of cyanobacteria will likely increase (Johnk et al., 2008; Paerl and Huisman, 2008). Many reasons explain this increase in bloom: higher temperatures favour the cyanobacteria growth, the warming of the surface water will reducing vertical mixing, and there will be an increase of the growth period to an earlier shift of stratification in spring and late destratification in autumn. Mooij et al. (2005) reviewing the impact of climate change on lakes in the Netherlands also report the increased presence of cyanobacteria and their predominance in the phytoplankton community. The increased loading of nutrients for instance under severe storms or wet winters followed by dry or drought condition and associated increased residence time will increase algae blooms (Paerl and Huisman, 2008). Arheimer et al. (2005) concludes also that under climate change, the increased amount of inorganic nitrogen entering the Ronnae lake (Sweden) will stimulate algae growth resulting in increased concentrations of cyanobacteria, zooplankton and detritus. Similar effects are reported by Whitehead et al. (2009). For additional information on the effects of climate change on coastal and marine waters and the implication for the link between nitrogen and carbon cycle see Voß et al., 2011 (Chapter 8 this volume).

Studies at the European scale have shown that climate changes are expected to alter the soil nitrogen cycle with great regional variability (Bouraoui and Aloe, 2007), and to exacerbate the problem of eutrophication, enhancing algal blooms and new harmful invasive algae (project EURO-LIMPACS, Battarbee et al., 2008). All these studies are affected by uncertainty, but some of the climate change effects are already being observed in European water ecosystems (Battarbee et al., 2008; European Environment Agency, 2008).

\subsubsection{Nitrogen fate under future land use changes}

Due to the interdependence of the world economic and ecological systems, prospective scenarios of human activities in watersheds should be conceived at the global level. The Millenium Ecosystem Assessment has provided the story lines of four scenarios of the world future named Global Orchestration (GO), Order from Strength (OS), Technogarden (TG), and Adapting Mosaic (AM) (Alcamo et al., 2006). The scenarios differ in terms of environmental management (pro-active or reactive) and in the degree of connectedness among and within institutions across country borders (globalisation or regionalisation). Technogarden and 
Table 17.3 Total nitrogen and total phosphorus river load to European coastal waters calculated by the GlobalNEWS models for 2000 and for 2030-2050 according to the two extreme Millenium Ecosystem Assessment scenarios

$\begin{array}{lll}\text { Scenario } & \begin{array}{l}\text { Total } \\ \text { nitrogen } \\ \text { load (TgN/yr) }\end{array} & \begin{array}{l}\text { Total } \\ \text { phosphorus } \\ \text { load (TgP/yr) }\end{array} \\ \text { 2000 reference } & 4.04 & 0.59 \\ \text { 2030 Global Orchestration } & 4.01 & 0.56 \\ \text { 2050 Global Orchestration } & 3.99 & 0.54 \\ \text { 2030 Adapting Mosaic } & 3.64 & 0.55 \\ \text { 2050 Adapting Mosaic } & 3.50 & 0.53\end{array}$

Adapting Mosaic were developed assuming pro-active environmental management, while Order from Strength and Global Orchestration assume reactive environmental management. Global Orchestration and Technogarden reflect trends towards globalisation, while regionalisation is assumed in Order from Strength and Adapting Mosaic. The IMAGE and GlobalNEWS models of watershed nutrient fluxes have been used to calculate nitrogen and phosphorus delivery at the outlet of 5700 world watersheds (Seitzinger et al., 2009). The results for European watersheds are shown in Table 17.3 for the two more contrasted scenarios GO and AM.

The trends shown are the results of several opposite drivers. The number of inhabitants with a sewage connection will further increase in all scenarios, but the removal of nitrogen in wastewater treatment also increases. On the other hand, the overall nitrogen use efficiency in agricultural production in Europe increases in all scenarios, particularly Adapting Mosaic $(\mathrm{AM})$, and this leads to an overall reduction of nitrogen river export. In the GO scenario there is also an increasing production. In AM, with a faster population growth than in GO between 2000 and 2030, the nitrogen export will decrease. This is caused by a combination of lower meat consumption and a major effort in better incorporating animal manure in the agricultural system.

Although global scenarios are best able to take into account the interconnected nature of world economies, there is also a need to increase the spatial resolution of their simulated results, in order to examine them at the sub-regional scale, closer to that at which management decisions are to be taken. With this in mind, Thieu et al. (2010a) proposed an interacting approach in which a sub-regional watershed model makes use of a background of 'large-scale-scenario' constraints provided by global models and enhances them by integrating sub-regional dynamics. Applying this approach to downscale the Global-NEWS predictions of the Millennium Ecosystem Assessment scenarios to the Seine, Somme and Scheldt watersheds, they predicted an overall increase of nitrogen delivery to the Southern Bight of the North Sea at the 2050 horizon in the GO scenario while the predictions indicate a decrease by about $20 \%$ in the AM scenario.

Several studies have looked at the impact of future land use and land management on nutrient losses. Bouwman et al. (2005a) predicted that from 1995 to 2030 in Western Europe grassland area will decrease from 60 Mha to $53 \mathrm{Mha}$ and arable land will decline from 86 Mha to $76 \mathrm{Mha}$. On the other hand for transition countries (including new member states and the old states of the USSR) for the same period grassland will increase from 90 Mha to $96 \mathrm{Mha}$ and arable land areas from 266 Mha to 273 Mha. At the same time, the nitrogen recovery has steadily increased for Western Europe from $44 \%$ in 1970 to a predicted $58 \%$ in 2030 . A similar trend is foreseen for transition countries with a predicted change of nitrogen recovery from $38 \%$ in 1970 to $58 \%$ in 2030 . This indicates an increase in productivity for both Western Europe and transition countries. Indeed for Western Europe, the level of fertiliser use in 2030 is predicted to be similar to that of 1995 . For transition countries, there should be an increase of nitrogen fertiliser use by about 25\%. Similar conclusions are reported by the EFMA in its 2008 outlook for 2018 (EFMA, 2008). EFMA (2008) expects that crop yield will increase for all major crops including wheat, barley, maize, potatoes and oilseed rape. It also predicts a shift in the agricultural production more oriented to grain and oil seed rape productions. This should lead to an increase of nitrogen consumption of $8 \%$ and $23 \%$, for wheat and oil seed rape respectively. EFMA (2008) expects a decrease of nitrogen consumption in fodder and grassland production. Overall it is predicted that for 2018, the nitrogen consumption will increase by $3.8 \%$ in Europe, mostly in the new Member States. Indeed, there is a continuing decreasing trend of nitrogen consumption in EU15 with the exception of Austria, Denmark and Sweden due to an increase in the area devoted to the production of energy crops. On the other hand for EU12 there should be an increase of nitrogen consumption by about $17 \%$ compared to the actual level. The impact of the changing environment on nitrogen losses are reported in Bouwman et al. (2005b, 2005c). Because of the predicted increase in nitrogen recovery, there should be no increase of total nitrogen emissions (sum of denitrification, leaching and volatilisation) in 2030 when compared to the actual levels.

Land use and climate changes are inherently interconnected by nature, and are both affected by the economic development and the mitigation and adaptation strategies adopted by the human society. Therefore future changes will be the result of complex interactions and will depend as well on societal choices. An actual example in this sense is the controversial issue of biofuels, which are motivated by economic and energy policies and present implications for both land use and climate changes, with expected negative consequences for water availability and nitrogen losses (Howarth et al., 2009).

\subsubsection{Possible management scenarios}

Global scenarios address the effects on the environment of possible future economic development at global scale. At local scale, scenarios of implementation of practical measures to reduce nitrogen pollution may be evaluated to plan effective remediation strategies at river basin level. A number of modelling studies have been published to assess the effect of measures to reduce nitrogen loads to waters, such as improved wastewater 
treatment, or from adoption of agro-environmental measures affecting agricultural practices or landscape management. The severely eutrophied continental coast of the Channel and the Southern North Sea is particularly well documented from that respect.

Cugier et al. (2005) explored the effect of phosphorus and/ or nitrogen tertiary treatment of urban wastewater in the Seine watershed, assuming constant agricultural diffuse sources, on the conditions of algal growth in the Seine Bight. Phosphorus treatment of wastewater (reducing the loading by 90\%) appeared as quite an effective measure to reduce the potentially harmful algal blooms in the Seine Bight, with a 10-fold reduction for maximum dinoflagellates biomass with respect to reference levels. To reach a result similar to that for phosphorus, the reduction of point sources nitrogen should be carried up to $70 \%$, which is technically feasible but extremely expensive. A reduction by $90 \%$ of point source nitrogen inputs would be required to lead the trophic state of the Seine Bight back to levels of flagellate development comparable to those of preindustrial periods.

More recently, Thieu et al. (2010b) generalised the same approach to the three main basins responsible for nutrient enrichment of the French and Belgian coastal zone of the North Sea (Seine, Somme and Scheldt, assuming that the Rhine plume is most of the time flowing northwards along the Netherlands coast). They showed that, although phosphorus abatement from the major point sources of wastewater is a useful measure to balance phosphorus fluxes with respect to silica inputs at the coastal zone, the generalisation of denitrification in wastewater treatment will not bring a substantial benefit. Implementation of 'good agricultural practices' (catch crop, reduction of fertilisation, extensification of cattle farming) would lead to a significant decrease of nitrogen fluxes exported to the sea, ranging from $14 \%$ to $23 \%$ in wet and dry years respectively. The results of these scenarios were coupled with a model of Phaeocystis development in the Southern North Sea (Lancelot et al., 2005, 2007). The combination of wastewater treatment improvement and good agricultural practices leads to a decrease of the Phaeocystis bloom duration from 25 to 20 days, and of the biomass peak from $35 \cdot 10^{6}$ to $30 \cdot 10^{6}$ cells/l. Previous works (Rousseau et al., 2000) showed, however, that the good status of the coastal marine ecosystem requires that the biomass of Phaeocystis cells never increases above $5 \cdot 10^{6}$ cells $/$, a threshold for the formation of ungrazable colonies (Lancelot et al., 2009).

Nitrogen contamination of surface and groundwater as well as of coastal sea water will thus remain a major problem even if 'good agricultural practices' were generalised. To further reduce nitrogen export, and more specifically to satisfy to the OSPAR (2005) recommendation of a 50\% reduction of nitrogen input to the sea, more drastic changes in agricultural practices should be envisaged. Essentially the same conclusion was reached by other authors working in different context and at various scales (Western France Kervidy catchment: Durand, 2004; England and Wales: Johnes et al., 2007 and Johnes 2007; The Elbe river: Kersebaum et al., 2003; Danish Gjern river: Kronvang et al., 1999b; Netherlands: Wolf et al., 2005).

\subsection{Policies for managing threats to European water quality}

\subsubsection{Policy and regulatory context}

At the beginning of the 1990s, the European Commission enforced various regulations to control and reduce nutrient loads into surface water, groundwater and coastal and marine water. In 1991, with the Nitrates Directive (Directive 91/676/EEC) and the Urban Waste Water Treatment Directive (Directive 91/271/EEC) the Commission started an ambitious plan to reduce the nutrient diffuse pollution originated from agriculture and the nutrient point pollution generated by urban waste water discharges. Then, the Commission established regulations for industrial emissions in 1996 (Directive 96/61/EC) and updated and reinforced the protection of drinking water in 1998 (Directive 98/83/EC). A comprehensive regulation for European water was enforced in year 2000, through the Water Framework Directive (WFD, Directive 2000/60/ EC) and its daughter directives. The WFD aims at protecting all the waters, including inland and coastal surface waters and groundwater and to achieve a good ecological status by 2015. It combines emission limit values with environmental quality standards. The WFD complements and integrates the European water legislation on nutrient reduction, in particular the Nitrate Directive and the Urban Waste Water Directive, into a coherent prospective of river basin management (Bloch, 2001). The Groundwater Directive (Directive 2006/118/EC) completes and specifies the WFD concerning the protection of aquifers, and the Freshwater Fish Directive (Directive 2006/44/ EC) sets physical and chemical parameters for fresh waters that support fish life, including among others limits for nitrite, total ammonium and non-ionised ammonia, which can be toxic for fishes. Finally, in 2008 the Marine Strategy Directive (Directive 2008/56/EC) was enforced to protect the marine environment, aiming to achieve or maintain a good environmental status for the European seas by 2021. Other European policies directly or indirectly influence the nitrogen enrichment in water, especially those related to the driving forces for nitrogen emission in the environment, such as the Common Agricultural Policy and the National Emission Ceiling Directive (Directive 2001/81/EC).

The Commission supports the implementation of the WFD and related policies through the Common Implementation Strategy, a joint work programme, which involves Member States, other countries, stakeholders and NGOs to promote dialogue, common understanding and best practice exchange. An example is the Pilot River Basin activity, where, among other issues, a network of European river basins is sharing knowledge and experience in developing and implementing measures to reduce nutrient pollution (Charlet, 2007; http:// prb-water-agri.jrc.ec.europa.eu/). Similarly, Member States are working together to establish common ways to evaluate the ecological status of water bodies through the Intercalibration process (European Commission, 2008). The latter compares national ecological assessments in order to ensure that 'good ecological status' means the same in all the European countries. Indeed, to ensure a similar level of ambition in setting 
the environment objectives in the European Union, the WFD mandated the intercalibration of the results of the national assessment methods. The boundary values for good ecological status for the different water types are established by the intercalibration exercise and will be the basis for setting environmental objectives for the management and programme of measures for the European river basins. The first step of the intercalibration exercise included a common agreement of reference condition criteria, and of the acceptable departures from the reference conditions. It was followed by the application of these criteria to a benchmark dataset to establish ecological rules, or if not possible statistical ones, for setting good status boundaries. An example is the data displayed in Figure 17.12 for lakes. Such data were obtained from national sources and from on-going EU projects that compiled EU wide biological datasets. (Further information can be obtained from the intercalibration technical report for lakes, the Commission decision on intercalibration and the following web address: http://circa.europa.eu/Members/irc/ jrc/jrc_eewai/library.)

When the common implementation strategy and the dialogue fail, the Commission can use its powers under the Treaty and take the non-compliant Member States to court.

In addition to European legislation, policies and interventions have been planned to protect European seas through international conventions: HELCOM in the Baltic Sea, OSPAR in the North Sea, the Barcelona convention MEDPOL in the Mediterranean Sea and the Bucharest convention in the Black Sea. For the river basins discharging in the North Sea, the OSPAR Convention established the reduction of inputs of nitrogen and phosphorus to areas affected or likely to be affected by eutrophication in the order of 50\% compared to input levels in 1985 , to be achieved by 1995 (PARCOM Recommendation $88 / 2$ and 89/4). Similarly, in the Baltic Sea within the HELCOM convention Contracting Parties committed to reduce nitrogen and phosphorus loads to the sea according to country specific reduction targets set in the recent Baltic Sea Protection Plan. A comprehensive discussion of European Directives and international actions addressing the nitrogen pollution through all the environmental compartments is presented in Oenema et al., 2011 (Chapter 4 this volume).

\subsubsection{Scientific and technical knowledge}

The research community has developed a sound understanding of sources and pathways causing water nitrogen enrichment and of the consequent processes of transformation, transport, storage and removal (Durand et al., 2011; Voss et al., 2011; Chapters 7 and 8, this volume). Effective tools that the scientific community can offer for understanding the impact of human disturbance and the potential success of restoration interventions include the construction of nutrient budgets at river basins scale (Billen et al., 2011, Chapter 13, this volume) and the spatial evaluation of pressures and sources contribution to nitrogen export (Johnes, 1996; Johnes and Heathwaite, 1997; Behrendt et al., 2003; Grizzetti et al., 2008) together with development and the evaluation of future scenarios (Bouwman et al., 2005c; Bouraoui and Aloe, 2007; Velthof et al., 2009). Moreover, the development of integrated indicators of nutrient pressure, eutrophication status and ecosystem functioning offers useful tools to monitor in space and in time nutrient trends and measures effectiveness (European Environment Agency, 2005).

Extensive knowledge is available on interventions to alleviate nitrogen (and phosphorus) pollution for the water system. Measures can be targeted on the sources, on the landscape or directly on the water body management (Novotny and Olem, 1994). They include among others: optimal fertilisation, where fertiliser application are reduced to match the crop requirements; spatial nutrient management, which implies lower application in areas with high erosion and runoff, use of catch crops to reduce erosion and nutrient leaching; improvement in livestock and manure surplus management; implementation of advanced treatments for waste water discharges; optimisation of sewer systems; creation of riparian strips, sedimentation ponds, appropriate drainage systems; and finally restoration of wetlands and floodplains to increase denitrification and protect wildlife habitat and biodiversity. A European initiative on this field is the COST Action 869 (COST 2010a) on mitigation options for nutrient reduction in surface water and groundwater. It provides an extended review of all the measures implemented in European countries describing for each measure main benefits, reported efficacy, region of application, likely disadvantages and potential costs (COST 2010b).

Economic tools, such as cost-benefit analysis (CBA), have been developed to support policy decisions on controversial environmental issues (OECD, 2006). CBA for environmental resolutions consists of calculating, commonly in currency units, the net benefits generated by the policy or project at each point in time, based on the analysis of all benefits and costs. Although widely employed, environmental CBA is controversial (Ludwig et al., 2005), for the way the discount rates are set and for the methods to account and monetise environmental externalities in the economic models. In fact, the evaluation of environmental effects and ecosystem services is not always possible in monetary terms, and implies a vision of the system and the actors concerned, involving definitely a discussion of values. Similarly, establishing discount rates requires a judgment in a time perspective. In economic models, discount rates indicate the way costs and benefits are weighted over time. When present benefits are weighted higher than future ones, ecosystem services are consumed faster, while the contrary produces the conservation of the natural capital with eventual wealth loss for the present generation (Ludwig et al., 2005). Therefore, the choice of the appropriate discount rate is not straightforward, involves a system of values and is undermined by the high uncertainty related to long-term pollution effects on ecosystems. However, evidence provides support for policies that maintain ecosystem services over the long term (Ludwig et al., 2005). Brink et al., 2011 (Chapter 22 this volume) provide a CBA of nitrogen in the environment with a European perspective. 


\subsubsection{Effects of implementation of measures}

To reduce eutrophication in estuaries and coastal waters programmes of measures implemented in their river basins will be essential to restrict anthropogenic nutrient inputs (Smith and Schindler, 2009). The WFD requires Member States to prepare river basins management plans including the analysis of nutrient pressures and the plan for implementing mitigation measures, in order to achieve by 2015 a 'good ecological status' of all the water bodies. The latter should be achieved considering the reference status, which refer to water body conditions prior to significant anthropogenic pollution. However, the concept of good ecological status implies some room for interpretation. In fact, even consistent nutrient abatement may not lead the water bodies to the desired status as many ecosystems present a hysterisis behaviour. Duarte et al. (2009) illustrated the trajectories of restoration in four North European coastal ecosystems (Marsdiep, Netherlands; Helgoland, Germany; Odense Fiord, Denmark and Gulf of Riga, Latvia/Estonia). They argued that in addition to nutrient enrichment other human induced changes, such as climate changes, population growth, freshwater withdrawal, may affect many fundamental factors of ecosystem functioning, producing baseline conditions different from those of the 'reference' status, even returning to pristine nutrient inputs. They observed that the restoration pathways of the monitored ecosystems followed dynamic trajectories of 'regime shift and shifting baseline'. As a consequence, when setting targets of restoration, emphasis should be put on the values ensuring reliable provision of ecosystem services and good ecosystem functioning rather than focusing on particular past conditions (Duarte et al., 2009). This does not mean that anthropogenic nutrient input should not be reduced; on the contrary these observations show a clear awareness on how human impacts can be difficult to reverse.

In Europe only $30 \%$ of surface water bodies have been identified as not being a risk of failing to achieve the WFD environmental objectives by 2015 , while $40 \%$ are at risk and for the rest $30 \%$ data are not sufficient for evaluation. The lack of information regards especially coastal and transitional water (European Commission 2007 SEC(2007)362). Similar figures are reported for groundwater bodies, with 25\% not at risk, 30\% at risk and for the remaining $45 \%$ the evaluation is not possible for the lack of data (European Commission 2007 SEC(2007)362). Nutrient diffuse pollution has been identified as one of the most significant and widespread pressures on water ecosystems in Europe (European Commission 2007 COM(2007)128).

In general during the past two decades the nutrient pollution from urban areas and point sources has been significantly reduced through the implementation of waste water treatment plants, while diffuse sources originate from agriculture remain a problem (European Environment Agency, 2005). According to the monitoring information transmitted by Member States, after almost 15 years from the enforcement of Nitrates Directive, in EU27 monitoring stations with average annual nitrate concentrations above $50 \mathrm{mgNO}_{3} / \mathrm{l}$ were $15 \%$ for groundwater and 3\% for surface water. Member States with the highest proportion of sampling points with nitrate concentrations above $50 \mathrm{mg} / \mathrm{l}$ were Estonia, the Netherland, Belgium, England, France, Northern Italy, North-East of Spain, Slovakia, Romania, Malta and Cyprus (European Commission $2010 \operatorname{COM}(2010) 47)$. In 2003, the level of compliance with the Urban Waste Water Treatment Directive in the EU15 was $79 \%$ in normal areas and $84 \%$ in sensitive areas (European Commission 2007 SEC(2007)363). There were 17 'big cities' still without wastewater treatment and some countries, mainly in Southern Europe, presented areas with inadequate or lacking wastewater treatment (European Commission 2007 SEC(2007)363).

Measures to reduce nitrogen and phosphorus pollution in water bodies have already been introduced in many European countries under the European legislation, international conventions and national plans. The assessment report on the implementation of the Baltic Sea Action Plan, under the HELCOM Convention, indicates that since 1990 nitrogen and phosphorus diffuse and point source loads have been slightly decreasing in the Baltic Sea catchment, however the target input levels foreseen in the Action Plan have not been met and additional reductions are needed (HELCOM, 2009). In the areas under the OSPAR Convention, the source reduction of $50 \%$ (compared to the level of 1985) has been met for phosphorus, but not completely for nitrogen. In fact, the target for nitrogen source reduction was achieved only by Denmark (in 2003), Germany and the Netherlands (both in 2005), although progress in this direction has been made also by the other Contracting Parties (OSPAR, 2008). See also Voss et al., 2011 (Chapter 8 this volume).

The implementation of programmes of measures for nutrient reduction varies in the European countries. Moreover, the water quality response to the mitigation programmes has been variable, depending on the design of the plans, the specific pollution conditions and the environmental characteristics. In general a delay has been observed between remediation actions and water response. In Denmark, the implementation of targeted regulations and nitrogen efficiency measures has reduced nitrogen loads to waters by $32 \%$, while maintaining the crop yield and increasing the livestock production (Kronvang et al., 2008). In Norway, results from long-term monitoring show that in spite of changes in management practices driven by subsidies and production conditions few correspondent trends were registered in nutrient losses (Bechmann et al., 2008). In part of England, the effect of actual measures introduced in the Nitrogen Vulnerable Zones is not evident and a time lag is expected because of the specific soils and aquifers characteristics (Jackson et al., 2008; Worrall et al., 2009). In Finland, no clear reduction of nutrient loads or water quality improvements were observed although a large-scale programme to reduce nutrient emissions from agriculture has been introduced since 1995 (Ekholm et al., 2007).

In general, scientific evidence shows that the adopted policies to reduce anthropogenic nutrient inputs to European seas were more effective in abating point sources than diffuse sources and more successful for phosphorus rather than for nitrogen, leading to the increase of the $\mathrm{N}: \mathrm{P}$ ratio in anthropogenic inputs (Artioli et al., 2008). Indeed, assessing policy effectiveness 
in reducing loads of nitrogen is controversial and presents regional differences. This is related to the diffuse nature of the sources, the tight connections with lifestyles, notably human diet, and the economic implications due to the links with agriculture and livestock production. Moreover, long-retention times of groundwater may retard the system recovery (Artioli et al., 2008).

In addition, the problem of 'pollution swapping' needs to be taken into wider consideration from both the scientific and the policy prospective (Stevens and Quinton, 2009). The term 'pollution swapping' is used to indicate when a mitigation measure reduces a targeted pollutant while increasing the level of another pollutant. Unfortunately, this side effect is present in many commonly implemented measures, but weakly considered in scientific studies and management plans. For example, constructed wetlands and riparian buffer zones are widely used to remove nitrogen but at the same time they promote denitrification, increasing the emissions of $\mathrm{N}_{2} \mathrm{O}$, a strong greenhouse gas, and thus swapping the pollution from water to the air compartment. If not correctly understood the mechanisms of pollution swapping may lead to contradicting interventions and unsuccessful regulations (Stevens and Quinton, 2009). An enlightening example in this sense is the model MITERRAEUROPE (Velthof et al., 2009), which provides an integrated assessment of the effect of nutrient mitigation measures in EU27 at country and regional level, considering the effects of mitigation measures contemporary on nitrogen emissions to atmosphere and to groundwater.

\subsubsection{Opportunities for policy and science integration}

In developing mitigation options for nitrogen pollution in water, the way forward is to adopt a more holistic approach in the policy frame, undertaking an integration effort in legislation tools and an evaluation of the potential 'ecosystem service swapping, and in the scientific research, promoting interdisciplinary studies including more forms of pollutants and all the environmental compartments (Stevens and Quinton, 2009; Collins and McGonigle, 2008).

Effective strategies to reduce eutrophication in aquatic ecosystems need to consider the whole land-ocean continuum and to control both nitrogen and phosphorus (Conley et al., 2009). A stronger integration between the Marine Strategy and relevant sectoral policies, such as the Common Agricultural Policy and the Fisheries Policy, would be beneficial for the sustainable management and protection of the marine ecosystem and its resources (Salomon, 2009). Similar positive synergies could derive from an improved coordination between policies to prevent water nutrient pollution and the Common Agricultural Policy and among the different nitrogen related regulations, in order to avoid problems of pollution swapping (Oenema et al., 2011, Chapter 4 this volume). The Commission already supports the integration between the implementation of different policies, encouraging Member States to use EU financing instruments available under the Common Agricultural Policy and the Cohesion Policy for improvements in the water field
(European Commission $2007 \operatorname{COM}(2007)$ 128), or the further integration of climate change mitigation and adaptation strategies into the implementation of EU water policy (see European Climate Change Programme). Finally, a strategic choice for the future will be to create positive synergies between River Basin Plans foreseen by the European WFD by December 2009 and international instruments, such as the Baltic Sea Action Plan (HELCOM Convention) or the OSPAR Resolutions (OSPAR Convention).

An effort to improve integration and interdisciplinarity is required also in the scientific research. Indeed, there is a need for integrated assessments to enable comparison between different regions for promoting regional assessment, and to evaluate the potential synergies between different type of policies or remediation measures, taking into account future scenarios.

There is a clear need to promote science-policy-society interactions to build reciprocal trust and understanding, and to produce a new type of transdisciplinarity knowledge to support a sustainable management of the ecosystem resources. In fact, the complexity of interactions of the human-ecological system cannot be addressed by traditional disciplines, but requires a new kind of interdisciplinary science, concerned by problem-solving aspects (Carpenter et al., 2009). This new type of knowledge production, also referred to as sustainability science, seeks to understand the interactions between nature and society, addressing the dynamics of the interactions, the longterm trends, the vulnerability and resilience of the naturesociety system and the opportunities for adaptive management and societal learning (Kates et al., 2001). To address problems related to sustainable development, the integration between natural science and social science is a key point and cooperation is necessary between the academic disciplines and the different parts of society (Tappeiner et al., 2007).

\subsection{Conclusions and way forward}

From the present overview it appears that the anthropogenic increase of nitrogen in water, together with other nutrients, causes many direct and indirect biogeochemical and ecological responses in the aquatic ecosystems, most of which are undesired and detrimental for the human-ecological system.

In spite of some encouraging trends, nitrogen concentrations in rivers, lakes, aquifers and coastal waters are generally high and stable in many regions, and even increasing in some areas. In addition, evidence shows that there is gradual and increasing nitrogen enrichment of groundwater resources across Europe. This poses direct threats to human health and ecosystem functioning, reducing the actual provision and the future reliability of ecosystem services.

A large part of European freshwaters and coastal waters are affected by eutrophication and current global drivers such as climate and land-use changes could exacerbate the situation in the near future. An additional challenge will be represented by the economic development of Eastern Europe, which could potentially lead to additional nitrogen loadings to the Baltic and Black Seas. 
Policy tools are available within the European Union and under international conventions to mitigate the nitrogen pollution in water. Their full implementation has not been achieved yet throughout Europe, but plans of measures to reduce nitrogen losses to water have already been implemented in many European countries, producing some encouraging results. However, in many cases a delay in the water quality response to the implementation of measures have been observed, due to previous accumulation of anthropogenic nitrogen in soils, sediments or aquifers or to inadequate design or targeting of the mitigation plans. At European level some regional differences have emerged in the sensitivity of coastal ecosystems to nutrient loads and on the effect of policy measures in changing the $\mathrm{N}: \mathrm{P}$ ratio. Finally, the issue of pollution swapping has appeared as an important element to be considered by both the scientific and policy perspective.

To support the sustainable management of the human-ecological system and promote the protection of water resources in relation to the threats posed by nitrogen in European water the full implementation of the regulations is necessary, combined with an efficient environmental monitoring. Moreover, positive synergies could be obtained by encouraging integration in the sectoral policies and enhancing interdisciplinarity in the scientific research, especially in support of regional assessments and pollution swapping evaluations.

The continuous nitrogen export to waters directly or indirectly threatens the biodiversity in the aquatic ecosystems, and slowly and gradually erodes the resilience of the aquatic ecosystems, increasing their vulnerability to other unexpected stresses. Water eutrophication and aquatic biodiversity loss have economic and political implications. According to Folke et al. (2002) two errors underpinned the past policies for managing natural resources. The first was the assumption that the ecosystem response to anthropogenic pressures is linear and the second was the lack of recognition of the mutual interdependence of the human and ecological system. Drastic changes in the ecosystem status may imply elevated costs for the direct loss of ecological and economic recourses and for the actions required for restoration. Building and maintaining the ecosystem resilience result in a wise investment for future human wealth, especially in the context of uncertainty and global environmental changes. A policy aiming at good ecological status can certainly contribute in this direction by investing in substantially improving nitrogen use efficiency and cleaning waste waters, in spite of the recovery time and costs.

\section{Acknowledgements}

This chapter was prepared with the support of the NinE Programme of the European Science Foundation, the NitroEurope Integrated Project (funded by the European Commission) and the COST Action 729.

\section{References}

Addiscott, T. M. (2005). Nitrate, Agriculture and Environment, CAB International, Wallingford, UK.

Alcamo, J., Van Vuuren, D. and Cramer W. (2006). Changes in ecosystem services and their drivers across the scenarios.
In: Ecosystems and Human Well-Being: Scenarios, ed. S. R. Carpenter et al., pp. 279-354, Island Press, Washington, DC.

Alcamo, J., Moreno, J. M., Nováky, B. et al. (2007). Europe, Climate Change 2007: Impacts, Adaptation and Vulnerability. Contribution of Working Group II to the Fourth Assessment Report of the Intergovernmental Panel on Climate Change. Cambridge University Press, Cambridge, UK, pp. 541-580.

Alexander, R. B., Smith, R. A. and Schwarz, G. E. (2000). Effect of stream channel size on the delivery of nitrogen to the Gulf of Mexico. Nature, 403, 758-761.

Alley, W. M., Healy, R. W., LaBaugh, J. W. and Reilly, T. E. (2002). Flow and storage in groundwater systems. Science, 296, 1985-1990.

Anderson, D. M., Glibert, P. M. and Burkholder, J. M. (2002). Harmful algal blooms and eutrophication: Nutrient sources, composition, and consequences. Estuaries, 25, 704-726.

Arheimer, B., Andreasson, J., Fogelberg, S. et al. (2005). Climate change impact on water quality: model results from southern Sweden. Ambio, 34(7), 559-566.

Artioli, Y., Friedrich, J., Gilbert, A. J. et al. (2008). Nutrient budgets for European seas: a measure of the effectiveness of nutrient reduction policies. Marine Pollution Bulletin, 56, 1609-1617.

Battarbee, R., Kernan, M., Livingstone, D. et al. (2008). Euro-limpacs Position Paper: Impact of climate change on European freshwater ecosystems: consequences, adaptation and policy.

Bechmann, M., Deelstra, J., Stålnacke, P. et al. (2008). Monitoring catchment scale agricultural pollution in Norway: policy instruments, implementation of mitigation methods and trends in nutrient and sediment losses. Environmental Science and Policy, 11, 102-114.

Behrendt, H., Bach, M., Kunkel, R. et al. (2003). Nutrient emissions into river basins of Germany on the basis of a harmonised procedure. Federal Environmental Agency (Umweltbundesamt).

Billen, G. and Garnier, J. (2007). River basin nutrient delivery to the coastal sea: assessing its potential to sustain new production of nonsiliceous algae. Marine Chemistry, 106, 148-160.

Billen, G., Silvestre, M., Grizzetti, B. et al. (2011). Nitrogen flows from European watersheds to coastal marine waters. In: The European Nitrogen Assessment, ed. M. A. Sutton, C. M. Howard, J. W. Erisman et al., Cambridge University Press.

Bloch, H. (2001). EU policy on nutrients emissions: legislation and implementation, Water Science and Technology, 44, 1-6.

Bouraoui, F., Galbiati, L. and Bidoglio, G. (2002). Climate change impacts on nutrient loads in the Yorkshire Ouse catchment (UK). Hydrology and Earth System Sciences, 6, 197-209.

Bouraoui, F., Grizzetti, B., Granlund, K., Rekolainen, S. and Bidoglio, G. (2004). Impact of climate change on the water cycle and nutrient losses in a Finnish catchment. Climatic Change, 66, 109-126.

Bouraoui, F. and Aloe, A. (2007). European agrochemicals geospatial loss estimator: model development and application. EUR Report 22690 EN, European Commission Joint Research Centre, Luxembourg.

Bouraoui, F., Grizzetti, B. and Aloe, A. (2009). Nutrient discharge from river to seas for year 2000, EUR Report $24002 \mathrm{EN}$, European Commission Joint Research Centre, Luxembourg.

Bouwman, A. F., van Drecht, G. and van Der Hoek, K. W. (2005a). Global and regional surface nitrogen balances in intensive agricultural production systems for the period 1970-2030. Pedosphere, 15, 137-155.

Bouwman, A. F., van Drecht, G. and van der Hoek, K. W. (2005b). Surface $\mathrm{N}$ balances and reactive $\mathrm{N}$ loss to the environment from 
global intensive agricultural production systems for the period 1970-2030. Science in China, Series C, 48, 767-779.

Bouwman, A. F., van Drecht, G., Knoop, J. M., Beusen, A. H. W. and Meinardi, C. R. (2005c). Exploring changes in river nitrogen export to the world's oceans. Global Biogeochemical Cycles, 19, 1-14.

Brink, C., van Grinsven, H., Jacobsen, B. H. et al. (2011). Costs and benefits of nitrogen in the environment. In: The European Nitrogen Assessment, ed. M. A. Sutton, C. M. Howard, J. W. Erisman et al., Cambridge University Press.

Burkholder, J. M., Tomasko, D. A. and Touchette, B. W. (2007). Seagrasses and eutrophication. Journal of Experimental Marine Biology and Ecology, 350, 46-72.

Caddy, J. F. (1993). Toward a comparative evaluation of human impacts on fishery ecosystems of enclosed and semi-enclosed seas. Reviews in Fisheries Science, 1, 57-95.

Camargo, J. A. and Alonso, A. (2006). Ecological and toxicological effects of inorganic nitrogen pollution in aquatic ecosystems: a global assessment. Environment International, 32, 831-849.

Cardoso, A. C., Duchemin, J., Magoarou, P. and Premazzi, G. (2001). Criteria for the identification of freshwaters subject to eutrophication: their use for the implementation of the Nitrates and Urban Waste Water treatment Directives. EUR Report 19810 EN, European Commission Joint Research Centre, Luxembourg.

Carpenter, S. R. and Folke, C. (2006). Ecology for transformation. Trends in Ecology and Evolution, 21, 309-315.

Carpenter, S. R., Caraco, N. F., Correll, D. L. et al. (1998). Nonpoint pollution of surface waters with phosphorus and nitrogen. Ecological Applications, 8, 559-568.

Carpenter, S. R., Mooney, H. A., Agard, J. et al. (2009). Science for managing ecosystem services: beyond the Millennium Ecosystem Assessment. Proceedings of the National Academy of Sciences of the United States of America, 106, 1305-1312.

Charlet, M. (2007). Experiences in the analysis of pressures and impacts from agriculture on water resources and developing a related programme of measures, European Commission Joint Research Centre, Luxembourg.

Christoffersen, K., Andersen, N., Søndergaard, M., Liboriussen, L. and Jeppesen, E. (2006). Implications of climate-enforced temperature increases on freshwater pico- and nanoplankton populations studied in artificial ponds during 16 months. Hydrobiologia, 560, 259-266.

Cloern, J.E. (2001). Our evolving conceptual model of the coastal eutrophication problem. Marine Ecology Progress Series, 210, 223-253.

Collins, A. L. and McGonigle, D. F. (2008). Monitoring and modelling diffuse pollution from agriculture for policy support: UK and European experience. Environmental Science and Policy, 11, 97-101.

Conley, D. J., Paerl, H. W., Howarth, R. W. et al. (2009). Ecology: controlling eutrophication - nitrogen and phosphorus. Science, 323, 1014-1015.

COST (2010a). http://www.cost869.alterra.nl

COST (2010b). http://www.cost869.alterra.nl/Fs/List_of_options. htm\#NM

Cugier, P., Billen, G., Guillaud, J. F., Garnier, J. and Ménesguen, A. (2005). Modelling eutrophication of the Seine Bight under present, historical and future Seine river nutrient loads. Journal of Hydrology, 304, 381-396.

Curtis, C. J., Evans, C., Helliwell, R. C. and Monteith, D. (2005a). Nitrate leaching as a confounding factor in chemical recovery from acidification in UK upland waters. Environmental Pollution, 137, 73-82.
Curtis, C. J., Botev, I., Camarero, L. et al. (2005b). Acidification in European mountain lake districts: a regional assessment of critical load exceedance. Aquatic Sciences, 67, 237-251.

De Roos, A. J., Ward, M. H., Lynch, C. F. and Cantor, K. P. (2003). Nitrate in public water supplies and the risk of colon and rectum cancers. Epidemiology, 14, 640-649.

Diaz, R. J. and Rosenberg, R. (2008). Spreading dead zones and consequences for marine ecosystems. Science, 321, 926-929.

Directive 91/271/EEC (1991) concerning urban waste water treatment. (OJ (1991) L271/40). (Urban Waste Water Directive).

Directive 91/676/EEC (1991) concerning the protection of waters against pollution caused by nitrates from agricultural sources $(\mathrm{OJ}$ (1991) L375/1). (Nitrates Directive).

Directive 96/61/EC (1996) concerning integrated pollution prevention and control (IPPC Directive).

Directive 98/83/EC (1998) on the quality of water intended for human consumption. (Drinking Water Directive).

Directive 2000/60/EC (2000) establishing a Framework for Community Action in the Field of Water Policy. (OJ (2000) L327/1). (Water Framework Directive).

Directive 2001/81/EC (2001) on national emission ceilings for certain atmospheric pollutants.

Directive 2006/44/EC (2006) on the quality of fresh waters needing protection or improvement in order to support fish life (OJ (2006) L264/20).

Directive 2006/118/EC (2006) on the protection of groundwater against pollution and deterioration (OJ L 372, 27.12.2006, p.19).

Directive 2008/56/EC (2008) establishing a framework for community action in the field of marine environmental policy (Marine Strategy Framework Directive) (OJ L 164, 25.6.2008, pp. 19-40).

Dodds, W. K., Bouska, W. W., Eitzmann, J. L. et al. (2009). Eutrophication of U.S. freshwaters: Analysis of potential economic damages. Environmental Science and Technology, 43, 12-19.

Duarte, C. M., Conley, D. J., Carstensen, J. and SanchezCamacho, M. (2009). Return to Neverland: shifting baselines affect eutrophication restoration targets. Estuaries and Coasts, 32, 29-36.

Ducharne, A., Baubion, C., Beaudoin, N. et al. (2007). Long term prospective of the Seine River system: confronting climatic and direct anthropogenic changes. Science of the Total Environment, 375(1-3), 292-311.

Durand, P. (2004). Simulating nitrogen budgets in complex farming systems using INCA: calibration and scenario analyses for the Kervidy catchment (W. France). Hydrology and Earth System Sciences, 8, 793-802.

Durand, P., Breuer, L., Johnes, P. et al. (2011). Nitrogen processes in aquatic ecosystems. In: The European Nitrogen Assessment, ed. M. A. Sutton, C. M. Howard, J. W. Erisman et al., Cambridge University Press.

EFMA (2008). Forecast of food, farming and fertiliser use in the European Union 2007-2017.

Eisenreich, S. J. (ed.) (2005). Climate Change and the European Water Dimension. European Commission, Joint Research Centre: Ispra, Italy.

Ekholm, P., Granlund, K., Kauppila, P. et al. (2007). Influence of EU policy on agricultural nutrient losses and the state of receiving surface waters in Finland. Agricultural and Food Science, 16, 282-300.

EMEP (2009). Transboundary acidification, eutrophication and ground level ozone in Europe in 2007, EMEP Status Report 2009, Norwegian Meteorological Institute, Oslo, Norway. 
Erisman, J.W., van Grinsven, H., Grizzetti, B., et al. (2011). The European nitrogen problem in a global perspective. In: The European Nitrogen Assessment, ed. M. A. Sutton, C. M. Howard, J. W. Erisman et al., Cambridge University Press.

European Commission (2007). The quality of drinking water in the European Union, Synthesis Report on the Quality of Drinking Water in the European Union period 2002-2004. (Directives 80/778/EEC and 98/83/EC).

European Commission (2007) COM(2007) 120. Report from the Commission to the Council and the European Parliament on the implementation of the Council Directive 91/676/EEC concerning the protection of the waters against pollution caused by nitrates from agricultural sources for the period 2000-2003.

European Commission (2007) COM(2007) 128. Communication from the Commission to the European Parliament and the Council 'Towards Sustainable Water Management in the European Union' First stage in the implementation of the Water Framework Directive 2000/60/EC.

European Commission (2007) SEC(2007) 362. Accompanying document to the communication from the Commission to the European Parliament and the Council 'Towards Sustainable Water Management in the European Union' First stage in the implementation of the Water Framework Directive 2000/60/EC.

European Commission (2007) SEC(2007) 363. Annex to the Communication from the Commission to the European Parliament and the Council 'Towards Sustainable Water Management in the European Union' First stage in the implementation of the Water Framework Directive 2000/60/ EC. 4th Commission Report (Executive Summary) on the Implementation of the Urban Waste Water Treatment Directive.

European Commission (2008). Commission Decision (2008/915/EC) of 30 October 2008 establishing, pursuant to Directive 2000/60/ EC of the European Parliament and of the Council, the values of the Member State monitoring system classifications as a result of the intercalibration exercise (notified under document number C(2008) 6016). OJ. L 332/20, 10/12/2008.

European Commission (2010) $\operatorname{COM}(2010) 47$. Report from the Commission to the Council and the European Parliament on the implementation of the Council Directive 91/676/EEC concerning the protection of the waters against pollution caused by nitrates from agricultural sources based on Member States reports for the period 2004-2007.

European Environment Agency (2001). Eutrophication in Europe's coastal waters, EEA, Copenhagen.

European Environment Agency (2005). The European environment: state and outlook 2005, EEA, Copenhagen.

European Environment Agency (2008). Impacts of Europe's changing climate, 2008 indicator-based assessment: Joint EEAJRC-WHO report. EEA Report 4/2008, EEA, Copenhagen.

European Environment Agency (2009). Progress towards the European 2010 biodiversity target. EEA Report 4/2009, EEA, Copenhagen.

Evans, C. D., Cullen, J. M., Alewell, C. et al. (2001). Recovery from acidification in European surface waters. Hydrology and Earth System Sciences, 5, 283-297.

Feuchtmayr, H., McKee, D., Harvey, I. F., Atkinson, D. and Moss, B. (2007). Response of macroinvertebrates to warming, nutrient addition and predation in large-scale mesocosm tanks. Hydrobiologia, 584, 425-432.

Flanagan, K. M., McCauley, E., Wrona, F. and Prowse, T. (2003). Climate change: the potential for latitudinal effects on algal biomass in aquatic ecosystems. Canadian Journal of Fisheries and Aquatic Sciences, 60, 635-639.

Folke, C., Carpenter, S., Elmqvist, T. et al. (2002). Resilience and sustainable development: building adaptive capacity in a world of transformations. Ambio, 31, 437-440.

Folke, C., Carpenter, S., Walker, B. et al. (2004). Regime shifts, resilience, and biodiversity in ecosystem management. Annual Review of Ecology, Evolution, and Systematics, 35, 557-581.

Galloway, J. N., Townsend, A. R., Erisman, J. W. et al. (2008). Transformation of the nitrogen cycle: recent trends, questions, and potential solutions. Science, 320, 889-892.

Glibert, P. M., Harrison, J., Heil, C. and Seitzinger, S. (2006). Escalating worldwide use of urea: a global change contributing to coastal eutrophication. Biogeochemistry, 77, 441-463.

Griesenbeck, J. S., Steck, M. D., Huber, J. C. et al. (2009). Development of estimates of dietary nitrates, nitrites, and nitrosamines for use with the short Willet food frequency questionnaire. Nutrition Journal, 8, 16.

Grimvall, A., Stalnacke, P. and Tonderski, A. (2000). Time scales of nutrient losses from land to sea: a European perspective. Ecological Engineering, 14, 363-371.

Grizzetti, B., Bouraoui, F. and De Marsily, G. (2008). Assessing nitrogen pressures on European surface water. Global Biogeochemical Cycles, 22, GB4023.

Gulis, G., Czompolyova, M. and Cerhan, J. R. (2002). An ecologic study of nitrate in municipal drinking water and cancer incidence in Trnava District, Slovakia. Environmental Research, A, 88, 182-187.

Hartikainen, H., Johnes, P. J., Monteith, C. and Okamura, B. (2009). Bryozoan populations reflect nutrient enrichment and productivity gradients in rivers. Freshwater Biology, pp. 1-15.

Hejzlar, J., Anthony, S., Arheimer, B. et al. (2009). Nitrogen and phosphorus retention in surface waters: an inter-comparison of predictions by catchment models of different complexity. Journal of Environmental Monitoring, 11, 584-593.

HELCOM (2009). Euthrophication in the Baltic Sea: an integrated thematic assessment of the effects of nutrient enrichment and euthrophication in the Baltic Sea region: Executive Summary, Helshinki Commission, Helsinki.

Hettelingh, J.-P., Posch, M., Slootweg, J. et al. (2007). Critical loads and dynamic modelling to assess European areas at risk of acidification and eutrophication. Water, Air and Soil Pollution, 7, 379-384.

Hettelingh, J.-P., Posch, M. and Slootweg, J. (2008). Critical load, dynamic modelling and impact assessment in Europe: CCE Status Report 2008. PBL Report 500090003, www.mnp.nl/cce, Coordination Centre for Effects, Bilthoven, The Netherlands.

Howarth, R. W. (1988). Nutrient limitation of net primary production in marine ecosystems. Annual Review of Ecology and Systematics, 19, 89-110.

Howarth, R. W., Billen, G., Swaney, D. et al. (1996). Regional nitrogen budgets and riverine $\mathrm{N}$ and $\mathrm{P}$ fluxes for the drainages to the North Atlantic Ocean: natural and human influences. Biogeochemistry, 35, 75-139.

Howarth, R. W., Bringezu, S., Bekunda, M. et al. (2009). Rapid assessment on biofuels and the environment: overview and key findings. In: R. W. Howarth and S. Bringezu (eds.), Biofuels: Environmental Consequences and Interactions with Changing Land Use, Proceedings of the Scientific Committee on Problems of the Environment (SCOPE) International Biofuels Project Rapid Assessment, 22-25 September 2008, Gummersbach 
Germany, pp. 1-13, Cornell University, Ithaca, NY, (http://cip. cornell.edu/biofuels/)

IARC (2006). Ingested nitrates and nitrites. http://monographs.iarc.fr/ ENG/Meetings/94-nitratenitrite.pdf

Jackson, B. M., Browne, C. A., Butler, A. P. et al. (2008). Nitrate transport in chalk catchments: monitoring, modelling and policy implications. Environmental Science and Policy, 11, $125-135$.

Johnes, P. J. (1996). Evaluation and management of the impact of land use change on the nitrogen and phosphorus load delivered to surface waters: the export coefficient modelling approach. Journal of Hydrology, 183, 323-349.

Johnes, P. J. and Heathwaite, A. L. (1997). Modelling the impact of land use change on water quality in agricultural catchments. Hydrological Processes, 11, 269-286.

Johnes, P. J. (2007). Meeting ecological restoration targets in European Waters: a challenge for animal agriculture. In: Redesigning Animal Agriculture: The Challenge for the 21st Century, pp. 185-203, CAB International, Wallingford, UK.

Johnes, P. J., Foy, R., Butterfield, D. and Haygarth, P. M. (2007). Land use for Good Ecological Status: an evaluation of scenarios for water bodies in England and Wales. Soil Use and Management, 23, 176-194.

Johnk, K. D., Huisman, J., Sharples, J. et al. (2008). Summer heatwaves promote blooms of harmful cyanobacteria. Global Change Biology, 14, 495-512.

Johnson, P. T. J., Chase, J. M., Dosch, K. L. et al. (2007). Aquatic eutrophication promotes pathogenic infection in amphibians. Proceedings of the National Academy of Sciences of the United States of America, 104, 15781-15786.

Kates, R. W., Clark, W. C., Corell, R. et al. (2001). Environment and development: Sustainability science. Science, 292, 641-642.

Kersebaum, K. C., Steidl, J., Bauer, O. and Piorr, H. P. (2003). Modelling scenarios to assess the effects of different agricultural management and land use options to reduce diffuse nitrogen pollution into the river Elbe. Physics and Chemistry of the Earth, 28, 537-545.

Kronvang, B., Hoffmann, C. C., Svendsen, L. M. et al. (1999a). Retention of nutrients in river basins. Aquatic Ecology, 33, 29-40.

Kronvang, B., Svendsen, L. M., Jensen, J. P. and Dørge, J. (1999b). Scenario analysis of nutrient management at the river basin scale. Hydrobiologia, 410, 207-212.

Kronvang, B., Andersen, H. E., Børgesen, C. et al. (2008). Effects of policy measures implemented in Denmark on nitrogen pollution of the aquatic environment. Environmental Science and Policy, 11, $144-152$.

L' hirondel, J. and L' hirondel, J. L. (2002). Nitrate and Man: Toxic, Harmless or Beneficial?, CAB International, Wallingford, UK.

Lancelot, C., Spitz, Y., Gypens, N. et al. (2005). Modelling diatom and Phaeocystis blooms and nutrient cycles in the Southern Bight of the North Sea: the MIRO model. Marine Ecology Progress Series, 289, 63-78.

Lancelot, C., Gypens, N., Billen, G., Garnier, J. and Roubeix, V. (2007). Testing an integrated river-ocean mathematical tool for linking marine eutrophication to land use: the Phaeocystis-dominated Belgian coastal zone (Southern North Sea) over the past 50 years. Journal of Marine Systems, 64, 216-228.

Lancelot, C., Rousseau, V. and Gypens, N. (2009). Ecologically based indicators for Phaeocystis disturbance in eutrophied Belgian coastal waters (Southern North Sea) based on field observations and ecological modelling. Journal of Sea Research, 61, 44-49.

Lavelle, P., Dugdale, R., Scholes, R. et al. (2005). Nutrient Cycling, Ecosystems and Human Well-Being: Current State and Trends, Washington, DC. Millennium Ecosystem Assessment. Island Press, 23.

Lotze, H. K., Lenihan, H. S., Bourque, B. J. et al. (2006). Depletion degradation, and recovery potential of estuaries and coastal seas. Science, 312, 1806-1809.

Ludwig, D., Brock, W. A. and Carpenter, S. R. (2005). Uncertainty in discount models and environmental accounting. Ecology and Society, 10(2).

McKee, D., Atkinson, D., Collings, S. E. et al. (2003). Response of freshwater microcosm communities to nutrients, fish, and elevated temperature during winter and summer. Limnology and Oceanography, 48, 707-722.

McKenzie, V. J. and Townsend, A. R. (2007). Parasitic and infectious disease responses to changing global nutrient cycles. EcoHealth, 4, 384-396.

Millennium Ecosystem Assessment (2005). Ecosystems and Human Well-Being: Synthesis, Island Press, Washington, DC.

Mimikou, M. A., Baltas, E., Varanou, E. and Pantazis, K. (2000). Regional impacts of climate change on water resources quantity and quality indicators. Journal of Hydrology, 234, 95-109.

Mooij, W. M., Hülsmann, S., De Senerpont Domis, L. N. et al. (2005). The impact of climate change on lakes in the Netherlands: a review. Aquatic Ecology, 39, 381-400.

Moss, B., McKee, D., Atkinson, D. et al. (2003). How important is climate? Effects of warming, nutrient addition and fish on phytoplankton in shallow lake microcosms. Journal of Applied Ecology, 40, 782-792.

Mulholland, P. J., Helton, A. M., Poole, G. C. et al. (2008). Stream denitrification across biomes and its response to anthropogenic nitrate loading. Nature, 452, 202-205.

Murdoch, P. S., Baron, J. S. and Miller, T. L. (2000). Potential effects of climate change on surface-water quality in North America. Journal of the American Water Resources Association, 36, 347-366.

National Research Council (2000). Clean Coastal Waters: Understanding and Reducing the Consequences of Nutrient Pollution, National Academy Press, Washington, DC.

Nixon, S. W. (1988). Physical energy inputs and the comparative ecology of lake and marine ecosystems. Limnology and Oceanography, 33, 1005-1025.

Novotny, V. and Olem, H. (1994). Water Quality: Prevention, Identification, and Management of Diffuse Pollution, Van Nostrand Reinhold, New York.

Oczkowski, A. and Nixon, S. (2008). Increasing nutrient concentrations and the rise and fall coastal fishery; a review of data from the Nile Delta, Egypt. Estuarine, Coastal, and Shelf Science, 77, 309-319.

OECD (1982). Eutrophication of Water, Monitoring, Assessment and Control, Organisation for Economic Co-operation and Development, Paris.

OECD (2006). Cost-Benefit Analysis and the Environment, Organisation for Economic Co-operation and Development, Paris.

OECD (2008). OECD Environmental Data COMPENDIUM 20062008, Organisation for Economic Co-operation and Development, Paris. 
Oenema, O., Bleeker, A., Braathen, N. A. et al. (2011). Nitrogen in current European policies. In: The European Nitrogen Assessment, ed. M. A. Sutton, C. M. Howard, J. W. Erisman et al., Cambridge University Press.

OSPAR (2005). Common Procedure for the Identification of the Eutrophication Status of the OSPAR Maritime Area, OSPAR, London.

OSPAR (2008). Nutrients in the Convention Area: Assessment of implementation of PARCOM Recommendations $88 / 2$ and $89 / 4$, OSPAR, London.

Paerl, H. W. and Huisman, J. (2008). Climate: blooms like it hot. Science, 320, 57-58.

Palmeri, L., Bendoricchio, G. and Artioli, Y. (2005). Modelling nutrient emissions from river systems and loads to the coastal zone: Po River case study, Italy. Ecological Modelling, 184, 37-53.

Phillips, G., Pietilainen, O. P., Carvalho, L. et al. (2008). Chlorophyllnutrient relationships of different lake types using a large European dataset. Aquatic Ecology, 42, 213-226.

Powlson, D. S., Addiscott, T. M., Benjamin, N. et al. (2008). When does nitrate become a risk for humans? Journal of Environmental Quality, 37, 291-295.

Rahel, F. J. and Olden, J. D. (2008). Assessing the effects of climate change on aquatic invasive species. Conservation Biology, 22, 521-533.

Rousseau, V., Becquevort, S., Parent, J. Y. et al. (2000). Trophic efficiency of the planktonic food web in a coastal ecosystem dominated by Phaeocystis colonies. Journal of Sea Research, 43, 357-372.

Salomez, J. and Hofman, G. (2003). Nitrates: a mixed blessing? Food Science and Technology, 17, 44-45.

Salomon, M. (2009). Recent European initiatives in marine protection policy: towards lasting protection for Europe's seas? Environmental Science and Policy, 12, 359-366.

Sanchez, P. A. and Swaminathan, M. S. (2005). Cutting world hunger in half. Science, 307, 357-359.

Scheffer, M., Carpenter, S., Foley, J. A., Folke, C. and Walker, B. (2001). Catastrophic shifts in ecosystems. Nature, 413, 591-596.

Schlesinger, W. H. (2009). On the fate of anthropogenic nitrogen. Proceedings of the National Academy of Sciences of the United States of America, 106, 203-208.

Schmidt, C. K. and Brauch, H. J. (2008). N,N-Dimethylsulfamide as precursor for N-Nitrosodimethylamine (NDMA) formation upon ozonation and its fate during drinking water treatment. Environmental Science and Technology, 42, 6340-6346.

Schreiber, H., Constantinescu, L. T. et al. (2003). Harmonised inventory of point and diffuse emissions of nitrogen and phosphorus for a transboundary river basin, http://danubis. icpot.org

Seitzinger, S., Harrison, J. A., Böhlke, J. K. et al. (2006). Denitrification across landscapes and waterscapes: a synthesis. Ecological Applications, 16, 2064-2090.

Seitzinger S. P., Mayorga E., Kroeze C. et al. (2009). Global river nutrient export trajectories 1970-2050: a Millennium Ecosystem Assessment scenario analysis. Global Biogeochemical Cycles, doi:10.1029/2009GB003587

Sileika, A. S., Stalnacke, P., Kutra, S., Gaigalis, K. and Berankiene, L. (2006). Temporal and spatial variation of nutrient levels in the Nemunas River (Lithuania and Belarus). Environmental Monitoring and Assessment, 122, 335-354.
Simpson, D., Aas, W., Bartnicki, J. et al. (2011). Atmospheric transport and deposition of nitrogen in Europe. In: The European Nitrogen Assessment, ed. M. A. Sutton, C. M. Howard, J. W. Erisman et al., Cambridge University Press.

Smith, V. H. (2003). Eutrophication of freshwater and coastal marine ecosystems: a global problem. Environmental Science and Pollution Research, 10, 126-139.

Smith, V. H. and Schindler, D. W. (2009). Eutrophication science: where do we go from here? Trends in Ecology and Evolution, 24, 201-207.

Stalnacke, P., Vandsemb, S. M., Vassiljev, A., Grimvall, A. and Jolankai, G. (2004). Changes in nutrient levels in some Eastern European rivers in response to large-scale changes in agriculture. Water Science and Technology, 49, 29-36.

Stevens, C. J. and Quinton, J. N. (2009). Policy implications of pollution swapping. Physics and Chemistry of the Earth, 34, 589-594.

Tappeiner, G., Tappeiner, U. and Walde, J. (2007). Integrating disciplinary research into an interdisciplinary framework: A case study in sustainability research: introduction to the special issue. Environmental Modeling and Assessment, 12, 253-256.

Thieu, V., Mayorga, E., Billen, G. and Garnier, J. (2010a). Subregional and downscaled global scenarios of nutrient transfer in river basins: Seine-Somme-Scheldt case study. Global Biogeochemical Cycles, 24, GB0A10.

Thieu, V., Garnier, J. and Billen, G. (2010b). Assessing impact of nutrients mitigation measures along rivers continuum to southern bight of the North Sea. Science of the Total Environment, 408, $1245-1255$.

UNESDA (2009). Union of European Beverages Associations.

van Drecht, G., Bouwman, A. F., Knoop, J. M., Beusen, A. H. W. and Meinardi, C. R. (2003). Global modeling of the fate of nitrogen from point and nonpoint sources in soils, groundwater, and surface water. Global Biogeochemical Cycles, 17, 26-31.

van Grinsven, H., Ward, M. H., Benjamin, N. and de Kok, T. M. C. M. (2006). Does the evidence about health risks associated with nitrate ingestion warrant an increase of the nitrate standard for drinking water? Environmental Health, 5, 5-26.

van Grinsven, H., Rabl, A. and de Kok, T. M. C. M. (2010). Estimation of incidence and social cost of colon cancer due to nitrate in drinking water in the EU: Quantative cost-benefit assessment. Environmental Health, 9(58).

Velthof, G. L., Oudendag, D., Witzke, H. P. et al. (2009). Integrated assessment of nitrogen losses from agriculture in EU-27 using MITERRA-EUROPE. Journal of Environmental Quality, 38, 402-417.

Vitousek, P. M., Aber, J. D., Howarth, R. W. et al. (1997). Human alteration of the global nitrogen cycle: sources and consequences. Ecological Applications, 7, 737-750.

Vollenweider, R. A. (1976). Advances in defining critical loading levels for phosphorus in lake eutrophication. Memorie dell' Istituto Italiana di Idrotiologia, 33, 53-83.

Voss, M., Baker, A., Bange, H.W. et al. (2011). Nitrogen processes in coastal and marine systems. In: The European Nitrogen Assessment, ed. M. A. Sutton, C. M. Howard, J. W. Erisman et al., Cambridge University Press.

Walker, B., Holling, C. S., Carpenter, S. R. and Kinzig, A. (2004). Resilience, adaptability and transformability in social-ecological systems. Ecology and Society, 9(2). 
Ward, M., de Kok, T., Levallois, P. et al. (2005). Drinking water nitrate and health: recent findings and research needs. Environmental Health Perspectives 113, 1607-1614.

Webb, A. J., Patel, N., Loukogeorgakis, S. et al. (2008). Acute blood pressure lowering, vasoprotective, and antiplatelet properties of dietary nitrate via bioconversion to nitrite. Hypertension, 51, 784-790.

Whitehead, P. G., Wilby, R. L., Battarbee, R. W., Kernan, M. and Wade, A. J. (2009). A review of the potential impacts of climate change on surface water quality. Hydrological Sciences Journal, 54, 101-123.

WHO (2007). Public Water Supply and Access to Improved Water Sources, World Heath Organization, Geneva.

Wilby, R. L., Whitehead, P. G., Wade, A. J. et al. (2006). Integrated modelling of climate change impacts on water resources and quality in a lowland catchment: River Kennet, UK. Journal of Hydrology, 330, 204-220.
Wolf, J., Rotter, R. and Oenema, O. (2005). Nutrient emission models in environmental policy evaluation at different scales: experience from the Netherlands. Agriculture, Ecosystems and Environment, 105, 291-306.

Worm, B., Barbier, E. B., Beaumont, N. et al. (2006). Impacts of biodiversity loss on ocean ecosystem services. Science, 314, 787-790.

Worrall, F., Spencer, E. and Burt, T. P. (2009). The effectiveness of nitrate vulnerable zones for limiting surface water nitrate concentrations. Journal of Hydrology, 370, 21-28.

Wriedt, G. and Bouraoui, F. (2009). Towards a large scale assessment of water availability in Europe, European Commission Joint Research Centre, Luxembourg.

Zhao, Y.-Y., Boyd, J. M., Woodbeck, M. et al. (2008). Formation of $\mathrm{N}$-nitrosamines from eleven disinfection treatments of seven eifferent surface waters. Environmental Science and Technology, 42, 4457-4862. 